OPIUM AND SEXUALITY IN LATE QING FIGTION

\title{
OPIUM AND SEXUALITY IN LATE QING FICTION
}

\author{
BY
}

\author{
KEITH MGMAHON \\ (University of Kansas)
}

\begin{abstract}
This article examines opium smoking in two gendered contexts of the late Qing, as an activity among socializing men and in situations between men and women. The method is to use fiction to ask how male and female smokers differed and in general to show how opium came to symbolize an uncanny and ominous disruption of the social fabric. In terms of gender, the obscene enjoyment of the female smoker was exponentially more threatening in the prohibitionist's eyes than that of the male. As the sign of an unprecedented type of pleasure, opium addiction threatened to denaturalize the boundaries of cultural as well as gender identity.
\end{abstract}

\section{Opium and the Wastrel}

\section{Opium smokers, male and female}

As opium became prominent in nineteenth-century Chinese life, it also made its debut in lives described in novels. There it became a new means by which the wastrel man could ruin himself. Of course, before "ruin" came the promise of a type of pleasure that exceeded any that had ever before been experienced. As an opium smoker named Zhang Changjia 張昌甲 once wrote (ca. 1878), the opium euphoria superseded all other pleasures, especially that of sex. ${ }^{1}$ The wastrel opium smoker will spend all he has on opium until he has nothing left, shamelessly giving up everything as he knew it for the sake of one more smoke. By the end of the Qing, this wastrel, who could be seen everywhere in real form, had also turned into a symbol. Both in the eyes of foreigners and of Chinese themselves, he

1 From Yanhua 镡話 ("Opium Talk") in A Ying 阿英, Yapian zhanzheng wenxueji 牌牌爭文學集 (Beijing: Guji chubanshe, 1957), 769. This essay is a heavily revised part of a longer study on opium in nineteenth-century China. I have benefited from the comments of Harriet Zurndorfer, two anonymous reviewers, the generous editorial advice of Michael Nylan, and the skillful editing of Beata Grant. 
became a central figure of the failure and decline of China as a whole.

Starting with this trope of the opium wastrel, I examine the consequences of opium smoking in two special, gendered contexts: as an activity among socializing men and in situations between men and women, especially those sexually involved. My method is to use fiction to sketch the role of opium in the social and symbolic order of late Qing China by asking a series of questions: What role did opium play in the signification of social and sexual hierarchy? How was opium involved in the phenomenon of the attempted manipulation of others, including extortion and conniving? Who were the male smokers, who were the female, and how did they differ? How did opium function in brothels, families, and other situations where opium smoking and sexual interactions both occurred? Finally, how did opium come to symbolize the disruption of social order in general?

When I say opium offered men a new chance to ruin themselves, it is also to say that each of these men naturally believed that he was the exception. Opium would not be the end of him. He was in a position of privilege due to his time-honored possession of phallic authority. Meanwhile, gathering around him were less privileged men and women who were possessed of a new knowledge that opium guaranteed to them-namely, that opium, if they managed it correctly, would surely allow them to live off if not replace the wastrel man. The wastrel knew this, but also knew he had so much authority to spare that he could still smoke a great deal of opium and never, he believed, go to ruin. In his extreme form, he was a man who could enjoy more than anyone, be more obscene than anyone, but he dared anyone to think they could upstage or undermine him. His obscenity consisted in his open excess, that is, in such things as his commandeering of sexual partners, his smoking of the best Indian opium, or his willful and destructive expression of rage if someone crossed him.

The excess of the wastrel makes relevant another important reality about opium, its use as an aphrodisiac. This fact explains the predominance of opium in brothels and among prostitutes. But the aphrodisiac effect is also framed by the common knowledge that long-term and heavy use of opium has the effect of inhibiting sexual function. As the opium addict Zhang Changiia illustrated it, the young man at first smoked opium to enhance his pleasure and fortitude with prostitutes. But eventually the smoker no longer cared 
for prostitutes and simply wanted to withdraw to a chamber of his own where he could spend hours smoking, being high, and sleeping. ${ }^{2}$ Although by no means all men followed this path as sketched by Zhang Changjia, the idea is nevertheless projected that opium gives men the power to withdraw from sex with women and live lives of self-sufficient addiction. Although the addict likes to believe he can cut off his desire for women, as Zhang portrays it, the fate of the addict is in fact to find in opium a more demanding mistress, that is, a "worse" woman, than the real woman. Opium is the most demanding of lovers in its allowance of no other lovers, in other words.

Two contrasting ideas about male smokers thus need to be kept in mind in the readings of novels I provide below. One is the independence that opium appears to grant: the addict's ecstasy makes him careless about family, duty, sexual desire, commitment to this or that prostitute (there is always a better one he can switch to). The other is the way opium serves as a subtle but binding and inescapable link: the intensity of the effects of opium wash over and transform everyone involved in ways they can never entirely know - though they think they know. In other words, instead of opium as escape and replacement (of liquor, for example), opium only makes more demands on the man than he encountered before.

What of female smokers and women in general who had to associate with male smokers? Although in reality female opium smokers were far fewer than male, they were not so few among courtesans, who instead of ruining themselves were more likely to use opium with an eye to advancing their own interests, as portrayed in novels about courtesans. In a way that parallels opium, the prostitute was likewise a "worse" woman than the "real" woman. Instead of offering liberation from the women at home (wife or concubine), the prostitute of the opium wastrel causes him to lose everything and end up penniless and homeless. In the context of families where daughters, mothers, and wives smoke opium, they likewise do things no normally modest woman would ever do. In general, female addicts portrayed in novels act more desperately and make more demands than the normally modest woman would. The simple demand that she must have her opium is the most basic example.

Although there were fewer female smokers than male, the image of the female addict was more ominous and disturbing in that the

\footnotetext{
${ }^{2}$ A Ying, Tapian zhanzheng wenxuejt, 767.
} 
woman as addict suggested a more profound disruption of social order. This point is made in the anti-opium crusader's portrayal of the female addict giving birth to an addicted baby. Opium in this manifestation becomes a more powerful and diabolical force in undermining social cohesion than the effect of any male wastrel abandoning his family or even selling his wife and children in order to procure more opium. In short, the woman is more efficient and effective in creating ruin than the man.

The question we are thus asking in making these observations is: How were gendered subjects differently transformed by the effects of opium addiction? Any human body's reactions to opium will be roughly similar according to physiological measurements. But because of social factors, gender in particular, men and women were nevertheless capable of taking their "dope" in different ways. In effect, the central question of this study is: What "new" subjects were produced because of opium smoking? I suggest we approach this issue by thinking about how the power of opium euphoria produced detachments from normal social networks, and also how such detachments at special times created the semblance of gender and hierarchy reversal whereby men appeared to become emasculated and women phallicized.

Men drained of libido or women charging themselves with the energy of opium are the core examples of this emasculation and phallicization. At the same time, however, it is important to avoid the impression that opium only had drastic consequences or always (or "typically") produced emasculated men and phallicized women. For one thing, men and women are never in a symmetrical relationship to begin with, so that they never can simply and cleanly switch places. ${ }^{3}$ For another, opium was also something that should be considered "normal" in that great numbers of people took it for granted, smoked it without shame or secretiveness, and at the same time went about their daily affairs without being "taken over" by opium in the sense many - especially those who were anti-opiumtended to project. In other words, even though I have just spoken of the wastrel ruined by opium, this wastrel is also a metaphorical figure, an imaginary terminus, not a generalization of what happens to everyone. One of the main pictures I want to draw, then, is of the community of people who "routinely" smoked opium. The reason I

${ }^{3}$ On this lack of perfect symmetry, see Keith McMahon, Misers, Shrewes, and Polygamists (Durham: Duke University Press, 1995), 112-13, 118. 
focus on the sexual is in order to foreground the fact that the great majority of smokers were male - to foreground their maleness in other words - and also to concentrate on the erotics of opium smoking and the interactions surrounding it. The male community of smokers was an inside group with a common understanding expressed in language (the use of special terms), experience (e.g., craving, the varying qualities and types of opium), interests (as seen in the deals made in opium dens), and their general separateness from nonsmokers, especially those who considered opium smokers to be wasted people. This community and its commonalities also crossed to include women, and when this crossing occurred, smokers were marked in ways that were informed by gender. These ways included physical appearance (e.g., when a woman's looks were ruined by opium, the consequences were different than for men) and reproduction (female addicts were said to have difficulty conceiving, but also gave birth to addicted babies).

In order to examine these questions, it will first be necessary to recall the central place of the male polygamist in the Chinese gender hierarchy. We must also clarify the generic and historic contexts of fiction in order to realize important distinctions between the way opium is written about in fiction in contrast to other types of writing. Who opium smokers were is further illuminated by observing who did not smoke, a contrast that helps define the place of opium in the social and symbolic order of those marked and unmarked by opium, tobacco, and liquor. Only after dealing with these areas can we then trust ourselves to examine opium in fictional contexts, in which I will sketch the daily life and the community of opium smokers, the language used, and the types of relationships that occurred between smokers. To repeat what I have said above, the assumption throughout will be that the experience of opium smoking and addiction is always more than a physiological process that is more or less predictably the same from individual to individual. That experience is always overdetermined by factors of subjective identity, which in this

study will be mainly restricted to gender but also include class and social status, ethnic and national identities.

\section{The polygamist-wastrel}

In a previous work, I have discussed misers, shrews, polygamists, and other character types in eighteenth-century Chinese erotic fic- 
tion. ${ }^{4}$ My purpose there was to define gender hierarchies, family relationships, sexual economies, and the ways these characters symbolized conscious and unconscious positions in a grand social order. Characters assumed roles that they also at times exceeded, avoided, or otherwise deviated from. At the apex of that society was the polygamist, whose fantasy of unlimited access to as many women as possible was the most authoritative and commanding, but was also based on an underlying assumption of the innate inferiority of male sexual function in comparison to female. All other characters had to arrange themselves or be arranged around this centering model of desire and its assumption of the primacy of the male cycle of energy. Subordinates destroyed each other but also formed alliances through which they supported each other and achieved some measure of control over superiors. Novels of the nineteenth century inherit the character types of earlier fiction but are written in a time when the Chinese male primacy is disturbed by the intruding primacy of the "Western" cycle of energy. The profligate wastrel of earlier fiction also enters a qualitatively new realm as he now ruins himself and family with the help of opium.

Much of the fiction I have written about in this study is directly or indirectly focused around the erotic. One of the main uses of opium, again, was as an aphrodisiac. In his autobiographical piece called "Opium Talk," (Yanhua 煙話), the opium smoker Zhang Changjia writes about the overwhelming effects of addiction. His work can itself be thought of as 'an erotics of opium smoking', an activity that he and others commonly refer to as inducing passion and "lovesickness" (xiangsi 相思). ${ }^{5}$ Zhang writes of the opium excesses, the stages of addiction, and the methods by which an addict might achieve self-regulation (but only, he says, with the greatest difficulty ever experienced in the history of the world). To rephrase what I have said above about the male addict finding a worse woman in opium than in the real woman: the state of lovesickness is one in which the male smoker is as if involved with an unrequiting lover who at first throws him into ecstasy but then causes him to wane into despair and misery. The addict is completely gutted by this love, like a teased lover who can't escape being teased. It is as if opium turns the tables and teases him as he formerly teased the woman, never promising her anything. The male addict is also like

\footnotetext{
${ }^{4}$ See McMahon, Misers, Shrewes, and Polygamists.

${ }^{5}$ A Ying, Yapian, 774, 778.
} 
a polygamist who, in having many wives, tries never to fall under the spell of any single one, but who finds in opium a lover who irresistibly spellbinds him. Opium is the ultimate jealous lover who so bewitches him that he cannot find other lovers to dispel its power.

In the late Qing, the most privileged figure of the Chinese story is still the polygamist in the form of the wealthy male smoker who goes from experiencing opium as an aphrodisiac to suffering emasculation at the hands of what turns into an insatiable and fixating lovesickness. In what I would call the core opium allegory of nineteenth-century Chinese fiction, this male smoker takes the form of the wastrel son whose father indulges the addiction as a method of pacification. As preposterous as this story may at first sound, it was widespread as an item of proverbial wisdom about the so-called constructive use of opium. In one famous version, the father is a rich miser who deliberately addicts his son in order to keep him passive at home and thus prevent him from depleting family wealth on gambling and prostitutes. The plan backfires, however, and as found in pictorial, fictional, and even cinematic representations in late Qing and early Republican China, the son brings complete ruin upon himself and his family. In an alternate version of this story, instead of deliberately addicting his son, the father merely indulges and tolerates his son's addiction, thinking at least to save face by having a son who supposedly stays obediently at home. Whatever version it may be, the life of the opium wastrel also becomes an allegory for the ruin of China, while the chief culprit for this ruin is the greedy merchant from the "Western seas" - thus the accusation found in countless documents and heard by Westerners in their exchanges with Chinese of all levels.

The totalizing allegory is one of opium addiction as a figure of the essential catastrophe of China in this period. Mingled in this story is the sense of helpless loss and devastation and of inferiority before the dominant outsider. In some late Qing satires, moreover, the Chinese are opium addicts because Chinese "would do that"; others, like the Westerners, know better. Such a totalization of opium is apparent not only in fiction and the common proverb, but in the late Qing politics of prohibitionism, especially the movements of the early 1900s. ${ }^{6}$ The eventual solution, if it can be called that, is an adoption of modernization that, in its ultimate twentieth-century

${ }^{6}$ Su Zhiliang 葆智良, Zhongguo dupinshi 中團毒品史 (Shanghai: Shanghai renmin chubanshe, 1997), 197-223. 
form, comes to a head in the Communist purge in the early $1950 \mathrm{~s}$ of opium, prostitution, gambling, polygamy, and all other signs of backwardness and decadence (the Republican government, of course, had also tried to control these). Any reliance on a foreign outsider will take on the appearance of addiction, which will therefore be categorically rejected in a move to create a new and pristine space of self-energized independence. Although these post-Qing developments get ahead of my story in this study (and the concept and practice of modernization are much more complex than this), it is essential in any understanding of Chinese history since the late Qing to view opium addiction in this allegorizing way as a figure of Chinese dependence upon and abjection before modernizing Western nations.

\section{The Social and Generic Contexts of Fiction}

Before returning to the specifically gendered aspects of opium smoking in the late Qing, we must consider the social and generic contexts of fiction at that time. In the novels I will be discussing, opium usually appears as a normal part of life that the author subordinates to more important themes. A notable exception occurs in Peng Yang'ou's 彭洋鴫 1909 novel, Souls from the Land of Darkness (Heiji yuanhun 黑籍冤魂), which besides Zhang Changjia's "Opium Talk" is one of the most valuable literary sources on opium smoking in the late Qing. ' This author attempts in twenty-four chapters to retell the story of opium smoking from the beginning - in his words, to provide a "portrait in miniature." He starts from the fictional first

\footnotetext{
From edition in A Ying, Wan Oing wenxue congchao: xiaoshuo sanjuan

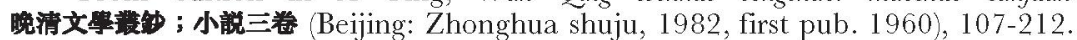
There are also a story (by Wu Jianren 吳䀘人, a play (by Xu Fumin 許復民), and a movie (director Zhang Shichuan 張石川) with the same title. The movie appeared in Shanghai in 1916. Adapted from the play, it is about a miser who forces his overly generous son to become an opium addict. Some plot elements appear in both the play and Peng's novel: e.g, a child mistakenly swallowing opium and dying, and underlings in the rich household mismanaging and appropriating family wealth. See Cheng Jihua 程季華, ed., Zhongguo dianying fazhanshi 中國電影綮展史 (Beijing: Zhongguo dianying chubanshe, 1963), 23-28, and Jonathan Spence, "Opium," in Spence, Chinese Roundabout (New York: Norton, 1992), 228-56, who refers (p. 230) to Jay Leyda, Dianying: Electric Shadows (Cambridge: MIT Press, 1972), 17-18.

8 Xiaozhao 小照, Ch. 1, 110. In novel citations, the format will be chapter number followed by page number, as here.
} 
addict and his invention of the Chinese opium pipe, then continues to the late Qing days of industrialized Shanghai and the pan-addiction that he presents as the central cause of China's degeneration. He writes at a time during the late Qing when the movement of opium prohibition linked with an emerging discourse of nationalism to effect a significant though brief and far from thorough decrease in opium production. ${ }^{9}$ As the scholars $\mathrm{Yu}$ Ende 于恩德 and $\mathrm{Su}$ Zhiliang 蘇智良 demonstrate, many writers, leading figures, organizations, and publishing concerns, especially newspapers, united in the energetic condemnation of opium smoking. ${ }^{10}$ Literature and eventually cinema joined the effort, along with Western missionaries and Western and Chinese medical experts. Many Chinese people knew that foreigners commonly saw the Chinese as an addicted and degenerate race. ${ }^{11}$ The governments of the late Qing in its last few years and the Republic in its first few years responded with legislation and enforcement that along with international treaties on narcotics control resulted in a more concerted effort at prohibition than ever before. ${ }^{12}$

In taking opium as an essential problem of China, Peng Yang'ou puts the problem in narrative form and keeps the explicitly propagandizing voice to a relative minimum. Many other Qing novels also contain stories and scenes of opium smoking, including the earliest that I know of, Tower of Elegant View (Yaguan lou 雅觀樓, ca. 1820); the mid-century novels Dream of Moon and Romance (Fengyue meng 風月夢, 1848) and Precious Mirror of Boy Actresses (Pinhua baojian 品花宔鑑, 1849); and the late Qing Flowers of the Sea (Haishanghua liezhuan 海上花列傳, 1892), Love among the Flower and Willow Girls (Hualiu shenqing zhuan 花柳深情傳, 1895), and The Vanity of Flourishing Life (Ershi zai fanhua meng 二十載繁華夢, 1907), among others. None of these works pretends to as broad a scope as Zhang's "Opium Talk" or Peng's Souls in the Land of Darkness. ${ }^{13}$ They nevertheless

${ }^{9}$ According to Su Zhiliang, 1910 production was $75 \%$ less than in 1906 . See $\mathrm{Su}$, Zhongguo dupinshi, 215.

${ }_{10} \mathrm{Yu}$ Ende, Zhongguo j̈nyan faling bianqianshi 中國禁橿法令隻連史 (Shanghai: Zhonghua shuju, 1934), 113-48; Su, Zhongguo dupinshi, 180-247.

$11 \mathrm{Su}$, Zhongguo dupinshi, 199-200.

12 For a detailed account, see Kathleen D. Lodwick, Crusaders Against Opium: Protestant Missionaries in China, 1874-1917 (Lexington: University Press of Kentucky, 1996).

${ }^{13}$ Zhang Chunfan's 張春帆 late Qing Heivu 黑喇 is another novel in which opium plays a large role, but I have not been able to see it. See also Haishang

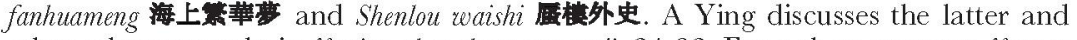
other relevant works in Tapian zhanzheng wenxuej, 24-32. For a short essay on Taguan 
collectively represent the pervasive acceptance and commonality of opium, in effect demonstrating what it is like when the proverbial "everyone" is addicted.

It is in these novels that I look for the daily life of opium smokers, by which I refer to the arena in which opium works as a dynamic and integral presence in a society in which great numbers of people smoke opium. Whether in fiction or reality, this so-called daily life of opium smokers is never innocent, as if apart from the judgment that laments or condemns it. As one would expect, this judgment is especially obvious in the novels that are overtly anti-opium. When Peng Yang'ou explains why and how so many Chinese came to smoke opium, he assumes the existence of culprits who set this scourge in motion. At the same time, neither he nor anyone else denies that opium is attractive and even useful and necessary. Within this framework of culprit and scourge, he and other novelists set forth to describe those who smoke anyway, that is, those who smoke despite the fact that a certain eye sees them as living wasted lives. Thus, before or while using their power as authors to administer poetic justice to their opium-smoking characters, these authors explain and motivate these characters, granting them, so to speak, the attractiveness of opium and their need to use it. These portrayals allow us to ask the questions about gender that I have raised above. As background to such questions, we must also search into such things as the occasions of opium consumption, the rituals and conventions that smokers observe, the motivations for and manner of smoking it (e.g., skillful vs. clumsy), and the relationships smokers are likely to form. Fiction, moreover, particularly enhances the discussion of opium smoking because of its concentration upon scenes involving the use of opium in sexual and marital couplings that few other sources are as likely to address.

Fiction must also be recognized in light of its specific historic and generic features, which distinguish it from other sources I will sometimes use, namely autobiographical accounts and the writings of Westerners in China, including their testimony in official settings (i.e., the British Royal Commission on Opium). From a reading of the works I cite, the most striking impression is that authors of vernacular fiction do not write about opium in an unabashedly posi-

lou see A Ying, Xiaoshuo xiantan sizhong 小晚閒談四種 (Shanghai: Guji chubanshe, 1985), Part 2, 157. See also Chloe Starr, "Shifting Boundaries: Gender in Pinhua baojian," Nan Nii 1.2 (1999): 268-302. 
tive manner. These authors seem to be following an unwritten agreement that indulgence in opium smoking is not something one should portray in a worthy person. The contrasting example of fictional descriptions of sexual activity clarifies this point. From early on, the Qing government explicitly mandated what subjects could and could not be written about, sex being one of the prohibited ones. Fictional works were frequently listed and banned if they violated these mandates. Many authors - almost all anonymous - wrote about sex anyway, and did so in an unabashed manner. The only texts in which I have seen affirmative or sympathetic evocation of opium euphoria, however, are short poems and passages in Zhang Changjia's "Opium Talk" and a few poems elsewhere. ${ }^{14}$ Even Zhang Changjia stops far short of merely foregrounding the opium euphoria. My point, nevertheless, is that if authors wrote enthusiastically about sex and other prohibited topics, they could also presumably have written about opium. But they did so only in poetry. When it came to narrative, the collective assumption was that opium smoking was for less than heroic characters. ${ }^{15}$ Those who were socially most respectable, in other words, never smoked opium.

An important historical note at this point is that in general fiction that reflected the epochal changes of the nineteenth century (like those that Zhang discussed in his 1878 "Opium Talk," for example) did not appear until the 1890s. At that time, fiction underwent energetic and rapidly innovative transformations. ${ }^{16}$ Opium in particular did not become part of an explicit political platform on the part of authors of fiction until those last two Qing decades. Only minor examples of anti-opium stances can be found in earlier works, such as the mid-century Trace of Flowers and Moon (Huayue hen 花月痕) and Tales of Boy and Girl Heroes (Ernü yingxiong zhuan 兒女英雄傳), which I will discuss below. Authors throughout generally portrayed opium

${ }_{14}$ See Gu Bingquan 㕍炳櫵, "Shanghai juzhicizhongde yangchang fumi fengxi" 上海竹枝調中的洋搨学風習, in Shanghaishi wenshiguan 上海市文史館, Fiu Shanghaide yan du chang 葆上海的煙睹姐 (Shanghai: Baijia chubanshe, 1988), 197.

${ }_{15}$ An exception is the central character Hong Shanqing 洪善卿 in Flowers of the Sea, a smoker like the author Han Bangqing 軿䛍度 himself, though not like Han someone versed in traditional education. Flowers of the Sea does not foreground or elevate opium, but neither does it particularly condemn it. Hong's smoking is a very minor part of his portrayal, almost even escaping the reader's attention (see Ch. 17). See Han Bangqing, Haishanghua liezhuan (Hainan: Hainan chubanshe, 1997).

${ }_{16}$ See Chen Pingyuan 椙平原, Zhongguo xiaoshuo xushi moshide zhuanbian 中國小

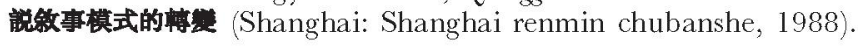


smoking as something degenerate, although they varied in the degrees to which they did so. In one rare case, however, Flowers of the Sea (1892), the author portrayed opium in a more or less neutral way in that he took no pains to condemn it in authorial asides or to demonstrate its evils in some heavily weighted way.

What this shared generic sense means, regardless of period, is that in terms of character portrayal, no one like Zhang Changjia appears in these novels. That is, wise and refined characters learned in the classical tradition cannot be opium smokers, even in Flowers of the Sea. Nor can characters who are self-consciously modern and reformist. If we were to hypothesize a novel that treated opium more affirmatively, it would be one, I think, in which the opium smoker was in some way linked with the tradition of great drinkers in Chinese history such as Tao Qian 陶潛 or Li Bo 李白. Such, at any rate, is the link suggested in Qing poetry about opium euphoria. The same logic applies in portrayals of sexual heroes in both Qing fiction and poetry. They are people of the finest learned and innate capacities, including sexual capacities. Both sexual heroes and opium smokers suffered the opprobrium of Confucian moralists, but opium smokers more so. If my hypothesis here is reasonable, it has in general to do with the fact that, compared to alcohol and sex, opium smoking was a latecomer, lacking tradition and canon. Moreover, it was too entwined with the arrival of Western domination and the loss of Chinese cultural integrity. As a result, it tended to become fixed as a causal and emblematic factor in China's so-called decline.

Another outstanding feature of these works has to do with their literary past, especially that of earlier Ming and Qing novels' portrayals of the character types of the polygamous family that I briefly discussed above. When, for example, the author of Precious Mirror of Boy Actresses engages in explicit depiction of sexual arousal and intercourse or of an operation on a venereally damaged penis, he cannot be read outside the context of an extremely large body of erotic literature containing similar locutions, clichés, paraphernalia, and even other close examinations of either the failing or prevailing penis. The participants in such scenes will have been met in some form before: rich philanderers (sometimes handsome and sensitive, sometimes grotesque and brutish), sexy courtesans or concubines, and young male lovers. Particularly central is the wastrel, who in the last half century or more of Qing fiction is also an opium wastrel. In numerous works from the early Qing up to the 1890 s or so, his virtuous opposite is a man of classic countenance who is temperate 
in all tastes and indulgences, whether he is monogamous or polygamous. By the time a new core of authors appears in the very late Qing (about the last two decades), such a virtuous opposite has become next to impossible to portray. The world of classical sensibility and the route of classical education have become anachronistic. Now only some kind of thoroughgoing change is possible.

\section{The Everyday Life of Smoking}

The most significant record these novels together provide is their representation of the pervasiveness of opium smoking, the particular vulnerability of the opium addict to framers and connivers, and the scene of male and female relations under opium, women addicts in particular. What follows in the rest of this essay is a collection with commentary of examples of what it is like when the proverbial "everyone" is addicted, including scenes and dialogues from everyday smokers as presented in these novels.

The proverbial everyone, as I have coined it, especially includes two types of people whom the prohibitionist deems the ones who should most avoid addiction: men in positions of responsibility and dignity, and mothers and children. The two aspects involved here are 1) political and social reproduction, and 2) generational or sexual reproduction, not necessarily evenly divided between male and female since both sexes obviously take part in each. But the male is predominantly in charge of the political sphere, while the female manages the domestic. The ultimate image in the prohibitionist's eyes is that of the Chinese as an opium people, with opium running in their veins instead of blood and with opium serving as currency rather than money. In the generational sense, especially, the culminating scene is that of father and mother both smoking opium. The appalled observer is like a child traumatized by watching the obscene enjoyment of his or her parents. The father should be dignified and in control, the mother wise and nurturing. If both are addicts, then the child is left with either hysterical trauma (terrified and immobilized by the obscenity of the parents) or the antiopium stance embodied in some version of radical reform and renewal. If the child him- or herself also becomes addicted, then in the late Qing anti-opium crusader's eyes, there will be no more healthy Chinese people.

Scenes that illustrate these points include those involving the rich 
addict Wu Rui'an 吳瑞㟟 (fourth-generation descendant of the opium-pipe progenitor) in Peng Yang'ou's novel, who buys the post of county magistrate and one day in his opium oblivion mistakenly burns an important official document. In great alarm he sends for his secretary, who is in his own room "passing his opium craving" (guo yin 過㴶), at which he takes so long that Wu finally goes over himself. The advice from his secretary is to confess, resign, and go back home (Ch. 7, 132). All work of local government is delayed, according to Peng, because everyone from the top down smokes opium. Since smokers sleep late, anyone with business at the yamen can only go late in the day (as the British Reverend Arthur Moule also discovered a few decades before). ${ }^{17}$ When sent on missions, yamen runners procrastinate or neglect their duties while they stop off to smoke opium. They take advantage of their connections with the yamen to smoke in dens without paying or paying less than the designated price (Ch. 23). Even teachers of young pupils smoke. One of them reclines in front of his class, takes a draw of opium, tells a boy to recite, takes another draw, hits this one, scolds that one, then finally gets up to hit at them all with his opium pipe (Ch. 23, 206). When people smoke with such little restraint, as Peng depicts, even the rats become addicted. One day a stench emerges from a deceased addict's opium room, where his family then discovers a mass of dead rats that had become addicted, run out of opium, and died (Ch. 13). ${ }^{18}$

The primary vehicle of the spread of opium smoking in Souls from the Land of Darkness is precisely that of generational descent. In Peng's

${ }_{17}$ As Moule (1836-1918) writes, "The Yamun officers told us that partly from the late habits formed by opium-smoking, and partly from the customs of the place, the court is open in the late evening for justice, and not in the daytime." See Arthur Evans Moule, New China and Old; Personal Recollections and Observations of Thirty Years (London: Seeley and Co., 1891), 145.

${ }_{18}$ However contrived and hyperbolic Peng's portrayals may seem, the element of truth would be recognized by readers who had examples of their own. In a poem from the mid-nineteenth century, The Bell of Qing Poetry (Qingshiduo 清詩䥁), rats in the rafters sniff rising opium smoke every time the smoker lights his pipe; the next morning the smoker finds rats fallen from the ceiling onto the floor. See poem by Fan Yuanwei 范元偉 in Zhang Yingchang 張密昌, ed., Oingshiduo (Beijing: Zhonghua shuju, 1983), 1008-9. Many thanks to Paul Ropp for showing me this section of Oingshiduo. In reference to French-occupied Annam, Cocteau wrote of the "dogs and monkeys that became addicted like their masters." "All animals," he said, "are charmed by opium. Addicts in the colonies know the danger of this bait for wild beasts and reptiles." See Jean Cocteau, Margaret Crosland, trans., Opium, the Illustrated Diary of his Cure (London: Peter Owen Publishers, 1996, originally 1930), 75 . 
rendition, the boundary between smoking parent and child who should not be allowed to smoke eventually breaks down. Knowing that he will not have the time to smoke opium that day, a father prepares an opium solution to drink in the morning and thus tide himself over. Left unattended, the solution is discovered by his seven-year-old son, who drinks it and dies. In this case, the mother is a nonaddict who dies of grief over her lost child (Chs. 11, 12). The effects of opium on both born and unborn children and on both male and female fertility was in fact a common source of justification in the prohibitionist argument. Reverend Moule (1891) quoted a doctor at the Mission Hospital in Ningpo: "Opium-smokers beget few and unhealthy children." "19 A passage in the 1895 anti-opium novel Love among the Flower and Willow Girls declares that the bones of the offspring of opium smokers are "all soft." 20 The same novel also portrays a man who is unable to father children because of his heavy addiction (Ch. 25). In Souls from the Land of Darkness, one man tells another of the harmful effects of starting opium too early in life: the body will fail to develop properly and one will be unable to have children. Babies born of addicted mothers will be addicted, too, the man warns, and will suffer from craving unless smoke is blown over their faces for them to inhale (Ch. 17, 174). The man who is told these things returns home to find his new baby daughter addicted at birth. Someone puffs opium at the baby, who finally stops crying, which makes everyone laugh with great mirth (Ch. 18, 180). In another late Qing novel, The Vanity of Flourishing Life (1907), a woman watching opera at home while smoking opium feels a pain and without warning or foreknowledge suddenly finds herself having a baby (Ch. 15). ${ }^{21}$

Both the laughter over a baby's addiction and suddenly giving birth while watching opera amount to minor details in the general picture of the routine acceptance of opium smoking. The implication in Peng Yang'ou's and other novelists' portrayals of opium

\footnotetext{
19 New China and Old, 98. Several witnesses before the Royal Commission on Opium also reported these findings. See Great Britain, Parliamentary Papers, 50, 51, 52, Reports and Minutes of Evidence of the Royal Commission on Opium (London: Eyre and Spottiswoode, 1894), e.g., 1: 30, 43, and 45. Hereafter, RRCO (the number preceding the colon will refer to the volume number, of which there are five in total, and the number or numbers after the colon will refer to the page.

20 Zhan Xi 角熙, Hualiu shenqing zhuan (Beijing: Beijing shifan daxue chubanshe, 1992), Ch. $20,84$.

${ }_{21}$ Huang Xiaopei 黃小劻, Ershizai fanhuameng, in A Ying, ed., Wan Qing wenxue congchao, 313-568.
} 
addiction is that an especially dangerous level is reached when women and children become addicts. The male wastrel is bad enough, in other words, but when the woman becomes a wastrel, then the rupture of the social fabric is complete. Thus Peng's demonstration of pan-addiction reaches its point of culmination, even though he does not articulate it in terms of gender. His novel ends instead with the suggestion that everyone in China will have to become addicted, at which point "God" will punish them all (Ch. $24,211)$. When these ghosts are then reborn, they will no longer be addicts and will thus eliminate the possibility that anyone will become one again.

\section{The Community and Language of Opium Smokers}

Opium smokers employed certain terms, used certain objects in common, and had certain smoking experiences with which a great many could identify. Fictional scenes representing these commonalities require much comparison and cross-referencing before specialized language, methods of smoking, and objects can be understood. Especially in the case of highly crafted paraphernalia, the terminology assumes either personal expertise or extreme familiarity on the part of the reader. I have concentrated on deciphering the process of smoking, but have not gone into the elaborate connoisseurship of paraphernalia, which, except for drawings, photos, and occasional basic utensils, I have not been able to examine.

Male smokers by far outnumbered female and were far more likely to smoke in groups. Within these groups, as in the community at large, the man was judged and sized up according to his appearance of dominance and social skill. But among smokers in particular, he was also judged according to his skill in the use of the opium pipe, the smoking of which was an art. One had to smoke in a convincing way. Convincing meant artful and masterful, but could also include ostentatious.

One possessed an eye (and a nose) for opium. If one did not already know whether a man smoked or not, someone else might chime in and identify him as a smoker and perhaps even a heavy smoker. A heavy smoker was likely to be rich (good opium was expensive, and smoking it, whatever its quality, consumed considerable amounts of time). He might be a good customer in the brothel 
or a good prospect for making deals with or taking advantage of in the course of socializing. The all-important factor of serving these male smokers included preparing the pipe, even placing it in his mouth, and knowing when he needed his opium, that is, when his "craving would come on." Since smoking before craving came on too strongly was critical, the predictability of craving was the focal marker of the addict and something by which to manipulate him.

If a woman was a heavy addict, she was especially noticed because of the effect of smoking on her appearance. Men could be uglier and more grotesque in their opium profligacy, but if a prostitute had the face of an addict, she had better be making plans that would take into account her changed appearance and its effects on her "business" (shengyi 生意). Some men liked an addicted prostitute, whose company for one thing might be cheaper (unless she had already accumulated enough wealth and prestige by that time to become independent). An unmarried daughter, on the other hand, could rely on the custom of female sequestration to keep her addiction and her appearance secret from her husband-to-be. But the reality of craving would nevertheless make it necessary for her to devise ways to maintain her habit at all costs. Again, the woman's "at all costs" was more desperate than the man's, which explains her greater need for developing a repertoire of schemes and skills in order to manipulate others to her advantage.

What follows is a selection of essential terms and scenes of opium smoking. The examples of women smokers are fewer, but will serve as a prelude to the discussion of their more specific situations later on.

The main designation for "smoking opium" in Chinese is chiyan 吃煙, to "consume" or "eat smoke," which can also refer to someone smoking tobacco. Simply saying "he or she is a smoker," ta shi ge chi yande 他是個吃煙的, most likely signifies that the person is a smoker of opium, not tobacco, although not necessarily a deep addict. If there is a need for clarity, someone might add, "he/she smokes the "big' smoke," ta chi dayan 大煙. "Big smoke" always means opium. Another common way to refer to the act of smoking is guo yin 過寉, to "get through," "pass," or to "satisfy one's craving." Someone who smokes in advance of a long day during which opium will be unavailable "must make sure to satisfy the craving to extra repletion," yin xu guo ge shifen $z u$ 應須過個十分足, as does a young bride early on her wedding day in Souls from the Land of Darkness. Her female servants help her smoke two "guns" at once, that is, two pipes set up 
side by side, in order to consume as much opium as possible in a short amount of time (Ch. 9, 138-40).

When one's "opium craving comes on," (yanyin laile 煙痽來了), one must satisfy it in order to avoid pain and discomfort. A man whose craving has come on arrives at a brothel that he frequents and asks someone to "hurry light a lamp and let me pass my craving" (Dream of Moon and Romance) ${ }^{22}$ If there is no time to smoke and a smoker is

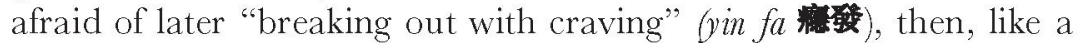
male character in Souls from the Land of Darkness, he takes some "raw opium" (shengyan 生煙, and mixes it in hot water; this is called “opium extract tea," (yan'gaotang 煙衰湯 or "soup," Ch. 11, 150). During the wedding day, the young bride's servants in Souls from the Land of Darkness slip her opium pellets (yanpao 煙泡), that is, raw opium cooked and rolled into a round pill-like form ready to smoke or, in this case, to swallow directly if necessary (Ch. 9, 139). ${ }^{23}$

Smokers recline when they smoke, often facing one another on either side of the lamp, that is, "passing their craving on either side of the gun" (dui qiang guo yin 對槍過應; Dream of Moon and Romance, Ch. 28, 201). In a scene from Dream of Moon and Romance, an experienced smoker teaches an inexperienced one, a young dandy who is interested in new sensations. The process goes like this:

Wu Zhen 题飨 twisted off the lid of the opium canister and placed it in the tray, then invited everyone to smoke .... Lying on the right side of the kang with Lu Shu Parta on the left, he dipped the iron needle into the opium in the canister and began cooking it over the flame of the lamp. When the opium swelled and distended about an inch, he twirled it on the needle and rolled it into a ball against the second finger of his left hand. He once again dipped this bit into the opium box, cooked it, and rolled it into another ball, then repeated this process several times until he had the right size opium bead. Taking the pipe, he brought it near the flame and fixed the bead into the cavity of the bowl, fitting it snugly with his finger. Then he took the needle and pierced a hole through the opium, still holding it near the lamp. He took the first turn to inhale, then wiped off the mouthpiece and handed the pipe to Lu Shu. (Ch. 3, 17)

22 Hanshang mengren 邗上蒙人, Fengyue meng (Beijing: Beijing daxue chubanshe, 1990), Ch. 11, 79. For a detailed study of this work, see Patrick Hanan, "Fengyue Meng and the Courtesan Novel," Harvard Joumal of Asiatic Studies, 58.2 (1998): 345-72.

${ }^{23}$ In his testimony to the Royal Commission on Opium, the missionary George Graham Brown, who spent six years in Lanzhou, mentioned the practice of eating crude opium in the form of little balls in order to relieve craving when one had no time to smoke (RRCO, 1:45). 
A novice like Lu Shu still lacks the feel for drawing in the smoke. With Wu Zhen holding the base of the pipe, Lu places his mouth over the mouthpiece and takes a draw, but inhales (xiu 嗅) so strongly that the venthole (doumen 斗門) clogs up. They repeat several times the process of recooking the opium and having $\mathrm{Lu}$ inhale again until "they finally finished smoking this one pipe." When an even clumsier smoker in Precious Mirror of Boy Actresses inhales (chou 抽), "he drooled saliva which dripped down the whole side of the pipe. He wiped his mouth with his fur sleeve and tried to inhale again, but only succeeded in clogging up the pipe." After a serving boy cleans the pipe for him, the man "took the opium needle and clumsily dipped up some opium, during which process he managed to burn a hole in his sleeve, which made everyone burst out laughing." 24

An expert smoker like Xi Shiyi 墨十一 in Precious Mirror of Boy Actresses, himself a trader in imported opium, has consummate technique, as the following passage shows. He is one of the prime examples in Qing fiction of the opium wastrel at his most excessive. He is known as someone with a "heavy opium addiction," (shi ge yapian dayin 是個鴉片大艘, who smokes one to two liang 雨 a day, that is, ten to twenty mace. But because he likes the strong Bengal opium (heitu 黑土), the prostitutes in the brothel he visits do not want to smoke with him. "Completely overcome" (zuidaole 醉倒了) by the stronger type, they only like the milder Malwa opium (baitu 白土). However, he finally finds a woman, Juhua 菊花, who doesn't mind smoking his kind of opium, although she smokes less of it.

This Xi Shiyi fellow liked to take big long draws when he smoked, so when Juhua cooked the opium for him she started with too tiny a bit for one draw and had to go to six times that amount before she got it just right. But she was an expert at preparing opium. She knew just the right balance between over- and undercooking it. Xi Shiyi especially liked what was called the "opium noodle," for which he took a needleful of opium and cooked it evenly all around until he could string it out about five inches. He fixed the bead around the smokehole and sucked it all in with one long draw, then closed his mouth tightly and didn't let the slightest bit out. This was his proudest and most consummate skill. (Ch. 18, 231-32)

\footnotetext{
${ }^{24}$ Chen Sen 秝, Pinhua baojian (Taibei: Guiguan tushu gongsi, 1986), Ch. 34, 424. A long description of inept opium smoking (with the pipe brought too close to the flame and the venthole clogging up) can also be found in Shenlou waishi (pre1895) cited in A Ying, Kapian zhanzheng wenxuët, 28-29.
} 
The method of smoking "opium noodle" (miantiao yan 猌佟煙) is portrayed with greater detail in a scene from Souls from the Land of Darkness in which an old male habitué of opium dens demonstrates his skill to a younger addict:

Stretching out his hand he took an opium needle, scooped up a large globule of opium and began cooking it. "My, what fine opium you have. See how far it draws out when you cook it, a good five inches. Say, do you know how to smoke 'opium noodle' [here written 棉枿䃏, "cotton-strand smoke"]? Let me show you." He cooked and rolled it twice more until he got it to stretch even more. Next he picked up the pipe and with a circular motion took this noodle-like string of opium and set it around the smokehole like the mound of a cow pie, which he smoked all up in one long draw. (Ch. 19, 187)

This scene evokes a seeming commonplace of opium dens: the role of the elder smoker who advises the younger. The man demonstrating the technique of "opium noodle" is nicknamed Baixiao 百曉, literally, "Knows Everything." He spends his time going from den to den and other places gathering news and gossip which he will divulge to those who share their opium with him. Before supplying the younger man with the desired information, the elder first smokes several pipes of opium. Later, after finishing the young man's purchase and seeing that the latter now ignores him, he arises and "cheerily ambles away, quite pleased with himself" (Ch. 19, 187). In another chapter of Souls from the Land of Darkness, a monk smoker lists the benefits of going to opium dens: "1) to relieve boredom, 2) to hear news, and 3) with so many smoking friends you never get lonely. Moreover, if you're having some trouble or difficulty, you can search out older smokers in the dens who can help you figure out some plan" (Ch. 13, 154).

Zhang Changiia does not mention opium dens, instead only speaking of meeting his opium friends more privately. Men in Precious Mirror of Boy Actresses mainly smoke together in their homes, but also in a monk-addict's apartments or in a special room adjoining a gourmet restaurant. Both exquisitely and miserably furnished opium dens existed, some attached to or combined with other enterprises, some relatively permanent, others mobile as they located themselves wherever they could to accommodate smokers on the road, for instance, or to avoid the harassment of the authorities. Zhang Changjia's declaration that smoking is better in solitude or selected company than in haphazard groups perhaps reflects a distaste for vulgar opium dens but also may have to do with factors he hardly 
mentions: the risks attending the semilegal and morally condemned status of opium smoking and the fact that such risks increased in the mixed company of some opium dens. Again, he writes his "Opium Talk" as living proof of the virtuous use of opium, although he admits his virtue is like forcing flowers to bloom in winter, that is, not quite as good as flowers blooming naturally in spring. ${ }^{25}$ Avoidance of dens notwithstanding, writing poems and digressions on the experience of opium smoking still includes providing advice to younger smokers and exchanging information and observations with other smokers of all ages.

\section{Those Who Did Not Smoke}

\section{The respectable class}

If opium smokers were allied in such ways, then who were the ones who did not fit in with this alliance? How were gender and subjectivity in general assumed in that one was marked or not marked as an opium smoker? As numerous Chinese and Western observers affirmed, opium smokers included people of all levels. At the same time, far from everyone smoked, and those who did not smoke also included people of all levels, especially women. At the extreme, the abstainer moved in a completely different social sphere in which he or she associated if possible with virtually no one who smoked. In portraying such people, nineteenth-century novels prior to the $1890 \mathrm{~s}$ in some cases nearly excluded the existence of opium smoking altogether. What was this non-opium way of life like in light of its virtual contiguity with its opposite? How, where, and by whom were the lines drawn between those who smoked and those who did not?

In terms of real numbers, Western and Chinese observers offered wildly varying estimates of how many Chinese had the opium habit, a number and percentage which, along with population growth, did indeed increase through the nineteenth century and into the twentieth. ${ }^{26}$ Among some groups (such as coolies and prostitutes) and in some areas of China (Shanxi and Gansu, for example), the percentages seemed very high, in some cases, according to Chinese esti-

25 A Ying, Yapian, 773.

${ }^{26}$ See Su Zhiliang, Zhongguo dupinshi, for more precise estimations of the progressively higher figures and the patterns they project. 
mate, up to eighty percent of men in the last quarter of the nineteenth century. ${ }^{27}$ Others, whether Western or Chinese, gave from about twenty percent to forty percent of men in the 1890s and usually estimated women smokers to be far fewer (e.g., one percent). ${ }^{28}$ James Legge and William Lockhart gave an even lower estimate, ten percent of men overall in the $1890 \mathrm{~s} .{ }^{29}$ Many then admitted that all such estimation was necessarily imprecise and, further, that smokers were not at all uniform: some smoked heavily, others hardly at all; some smoked for a certain period and purpose, then later no more. Those against opium, moreover, generally wanted estimates higher. Those who were not so distressed saw high numbers as well but argued that moderation was the rule. They often at the same time wanted to see the continuation of the system that generated such large revenue from opium production, transport, taxation, and sale. All agreed that the numbers of nonsmokers or rare smokers was very high, in fact higher than the total of regular smokers, however the latter were defined in terms of extent of use.

In the social universe of nineteenth and early twentieth century fiction, as I previously mentioned, I have not found anyone like Zhang Changija or his friends. No refined, upper-class characters smoke opium. These nonsmokers, moreover, tend to move in a social sphere in which no one else smokes, including household servants and nonliterati friends. Such is the case in all the novels mentioned so far and in other novels in which opium hardly figures at all: for example, The Trace of Flowers and Moon (Huayue hen 花月痕, preface 1858, with the last chapters probably completed in the $1860 \mathrm{~s}$ ), Tales of Boy and Girl Heroes (Ernü yingxiong zhuan 兒女英雄傳, first published in 1878, probably begun in the 1850s), and Dream of Courtesan Chambers (Qinglou meng 青樓葷, ca. 1878). Like Dream of Moon and Romance and Precious Mirror of Boy Actresses, these three novels precede the period of rapid and intense transformation that fiction underwent in the last decades of the Qing. They are novels in which characters of classical sensibilities still prevail and authors still write with minimal registration of the effects of such things as the Opium War and the situation of a China repeatedly forced to concede territory and rights to Western powers. The relative lack of reference to opium smoking, however, is not necessarily an avoidance of his-

\footnotetext{
27 Spence, "Opium," 237-38.

28 See RRCO, 5: Appendix XXVI, passim.

29 See Spence, "Opium," 238, citing RRCO, 1: 15-17, 113.
} 
torical realities. The Trace of Flowers and Moon is significantly marked by the disruption of the Taiping Rebellion. ${ }^{30}$ All three can be read as radical, even heroic, enactments of the refusal to be perturbed by the opium "evil" and to be dislodged and depressed by foreign encroachment. That heroism seems overly fantastic in retrospect, especially in contrast to many late Qing novels, but in its own context represents a devoted attempt to extend the world of classical themes and sensibilities.

If anyone smokes in these three works, it is a vulgar, villainous character or else someone who is portrayed as unfortunate and fallen. In the other novels I have discussed, smokers play much greater roles and include what are portrayed as decadent members of the literati, prostitutes, wealthy merchants, their male and female family members, government clerks or officials (that is, those of the sort who have bought their post instead of being assigned it because of meritorious performance in the civil examinations), or professionals or other associates of Beijing opera. However, a refined or pure member of any of these or other nonliterati groups, especially the courtesan or the boy actress, may also be an abstainer like the literatus.

An example of the villainous smoker appears in The Trace of Flowers and Moon, in which the brothel madam Niu 4 is an addict "who lies in bed all day" passing her craving but who will keep as tight a hold as she can on her property and moneymaker, the courtesan Qiuhen 秋痕. ${ }^{31}$ The madam later dies in a fire caused by having left an article of clothing too close to her opium lamp (Ch. 44, 368). She is the only addict portrayed in the book. The courtesan Qiuhen's vain hope is that her literatus lover will rescue her from prostitution. Along with him she is an absolute abstainer, and she writes for him a preface to a proposed set of poems on the scourge of opium (Ch. 31, 270-71). She knows, as she writes, that "virtuous" women sometimes smoke opium (that is, elite women), but that an overwhelming number of prostitutes typically do, among whom she is thus an outstanding exception.

Like The Trace of Flowers and Moon, the Dream of Courtesan Chambers is also about sensitive literati and their love affairs with talented

\footnotetext{
${ }^{30}$ See David Der-wei Wang, Fin-de-siècle Splendor: Repressed Modernities of Late Qing Fiction, 1849-1911 (Stanford: Stanford University Press, 1997), 73-81.

${ }_{31}$ Wei Zi'an 子安, Huavue hen (Fuzhou: Fujian renmin chubanshe, 1981), Ch. $24,202$.
} 
courtesans. Opium appears in two instances in this novel: when the hero Yixiang 揭香 displays his special hatred for a villainous opium addict, and when he saves one of the courtesans he loves, Aiqing 愛卵, who swallows opium in an attempted suicide. ${ }^{32}$ Yixiang and Aiqing are significant for what they are not: opium addicts, the male of whom is a wastrel who spends all he has on prostitutes, the female of whom smokes because that is the way of prostitutes in this period, as Qiuhen wrote in The Trace of Flowers and Moon. But the existence of opium is still prominent enough in their lives for Aiqing to swallow it to commit suicide when forced into a hopeless situation (like many other women then), ${ }^{33}$ and for Yixiang to recognize the odor of opium which issues from her nostrils after she tries to commit suicide.

Other than these minor episodes of opium involvement, these two novels are virtually devoid of opium smoking. ${ }^{34}$ The same is true of Tales of Boy and Girl Heroes, which portrays people from city and country of both heroic and villainous character. Opium is mentioned in passing in one exchange between an unjustly cashiered offical, An Xuehai 安擧海, and an elderly and illiterate countryman, Zheng Zhenbiao 鄭振劇, who was formerly a strongman and bodyguard for travellers and transported goods. At eighty-seven years old, Zheng is a vigorous and sometimes temperamental elder who commands respect from even a member of the educated class like An Xuehai, who seeks a favor of him. In order to meet Zheng's approval and win his cooperation, An visits him, and when offered tea, asks instead for something else he refrains from mentioning, which he "fears" Zheng may not have. Zheng "looked at him in consternation, 'You don't possibly mean that someone like you smokes opium, do you?"' To which An replied that what he meant

${ }^{32}$ Yu Da 俞達, Qinglou meng (Beijing: Beijing daxue chubanshe, 1990), Ch. 8, 53, and Ch. 20, 143.

${ }_{33}$ Yixiang saves her by prying open her mouth and putting his tongue inside to recover several bits of opium as yet unswallowed. She had had an argument with her madam, whose interest was for Aiqing to see more customers, whereas Aiqing only wanted to see Yixiang, whom she eventually succeeds in marrying. Miss Geraldine Guinness and William Lockhart, witnesses before the Royal Commission on Opium, reported the frequency of women using opium to commit suicide (RRCO, 1: 7, 114).

${ }^{34}$ The Trace of Flowers and Moon contains two more direct references. Qiuhen's lover has a poem of his own on the scourge of opium (Ch. 20, 165), and writes a memorial to the emperor which contains a passing condemnation of opium (Ch. $46,383)$. 
was Shaoxing wine. ${ }^{35}$ As An had previously been told, wine is precisely the way to Zheng's heart. After they begin to drink, An is able to enlist Zheng's help. ${ }^{36}$

Tales of Boy and Girl Heroes thus offers the example of nonsmokers of both moral and physical purity. An Xuehai is the traditional instance of the Confucian exemplar, although even he says of himself that he is too "stiff and impractical" (Ch. 13, 236). The uneducated but genuine countryman Zheng is an upright man still able both to fight and procreate: at his late age he takes a concubine who soon gives birth to healthy twins. Although anti-opium sentiment is not a major theme, these examples of vigorous and clean virtue are the author's stand-ins for what the world would be without opium. His replacements of opium are liquor and tobacco, the former of which is the hallowed favorite from earliest recorded history, the latter a recent introduction that, though opposed at first by Chinese rulers, finally became a staple. ${ }^{37}$ Tobacco appears throughout the novel as a custom among both gentry and commoner, virtuous and villainous, male and female. An Xuehai himself, however, likes only liquor. He declines to smoke several times when he is offered tobacco, including when he first drinks with Old Zheng, who is also a nonsmoker-Zheng likes to roll iron balls, tiequ 珴球, in his hand, a custom of self-styled hardy elderly men. Liquor is what the author promotes as the choice of these truly wholesome and virtuous men.

\section{Smokers and non-smokers in Precious Mirror of Boy Actresses}

In Precious Mirror of Boy Actresses, the line between virtuous and villainous is not drawn as clearly as in Tales of Boy and Girl Heroes, but the literati who do not smoke opium nevertheless form a distinct group, with only one area in which they cross into a lower class. The young men socialize with boys who are female impersonators in Beijing opera. Association with such people is something that the strictest households would normally forbid their sons, who should be gearing themselves for the civil examinations. These young men, however, have their special boy-actress friends and at the same time

\footnotetext{
${ }_{35}$ Wen Kang 文康, Ernü yingxiong zhuan (Jinan: Qilu shushe, 1989), Ch. 15, 283.

${ }^{36}$ Opium appears tangentially in one other scene in which observation is made of the activities at a temple fair. Among the many stalls selling goods or services, there is one selling a tool for scooping out opium extract. At this, An Xuehai does not even raise his head but instead scurries past without looking (Ch. 38, 926).

37 See Spence, "Opium," 238-39.
} 
prepare for and take the examinations. Moreover, the boy actresses in Precious Mirror share the refined sensibilities of their literati patrons and are likewise absolute abstainers. However, the owner and manager of the most famous boy actress is an opium smoker, as are some of the boy servants the manager employs. As for the women of the novel, none related to the literati males smokes, but as will be seen below, prostitutes and a concubine of Xi Shiyi, the most profligate smoker in the book, smoke opium both by themselves and in the company of others, both male and female.

The nonsmoking literati who live in households devoid of opium smoking sometimes cross paths or associate with other men who in separate settings gather with friends to smoke. But these literati nonsmokers would not even think of smoking and want to avoid even the smell of opium, which makes them feel "drunk" (Ch. 50, 636). When together, these young men drink alcohol and chant poetry, and if they drink excessively, they take a special herbal pill that reverses the effects of intoxication.

The following situation demonstrates the clean divide in this novel by which all opium smokers are in some way tainted because of their status, occupation, and moral behavior. Among the smokers, there are the heavy addicts who are fully conversant with the opium habit and the techniques and paraphernalia of smoking, and there are the novices or light smokers who still keep a distance from opium. Among the nonsmokers are the pure and virtuous; and there are those who live a life of hedonism but without opium. Even their hedonism is not very villainous compared with that of the opium wastrel. The key character in this episode is the opportunistic and sometimes unscrupulous young man, Wei Pincai 魏聘才, who at the beginning of the novel is a lesser peer of the main hero and handsome literatus, Mei Ziyu 梅子玉. Mei's friends are the young men just mentioned, who are all similarly talented and cultured sons of highly placed fathers. Like his father, Wei Pincai has not quite the talent and drive of the other young scholars who are preparing for the civil examinations, but likes to climb the social ladder. Thus he seeks employment as secretary to a wealthy official's son, Hua Guangsu 華光宿 and thereby gains power because of this influential connection. Instead of preparing for examinations, the rich Hua Guangsu himself spends his days in pleasurable but refined pursuits with his wife, maids, friends, and troupes of boy actresses. No opium smoking occurs in his household, Hua being a nonsmoker himself. But as cultured as he is, he is lavish and ostentatious in his expen- 
ditures and imperiously insistent upon having the best of all good things. When he discovers the famous boy actress Qinyan 琴言, he wants to acquire him for his private ring of talent that he houses in his palatial compound. He sends his secretary Wei Pincai as gobetween to persuade and pressure Qinyan's owner and manager, the opium smoker Cao Changqing 曹長慶, to release Qinyan to Hua Guangsu.

When Wei Pincai appears with a companion at the manager Cao Changqing's home, where the boy actress Qinyan also lives, Changqing at first judges Wei Pincai to be "someone of no great importance." But when Wei's companion announces that Wei works for Hua Guangsu, one of the greatest patrons of boy opera singers in Beijing, Changqing transforms himself into a gracious and fawning host who, after serving tea, brings out the opium lamp. With this gesture of hospitality, the visit takes on a new quality of engagement and duration: he now asks Wei and his companion to lie down and smoke. But Wei says he is still a novice and does not know how to light the pipe, at which point Changqing lights it and hands it to Wei, who "takes a draw" but then hands the pipe back saying, "I am an outsider to this art; pardon me if I don't return the favor." When Wei finally announces the purpose of his visit, Changqing becomes agitated because he does not want to part with such an illustrious and profitable talent as Qinyan, although he also knows that Hua Guangsu is powerful and insistent. As Wei presses harder, Changqing "takes a dozen or more draws of the pipe" and continues vainly trying to fend Wei off (Ch. 26, 322-23). Eventually, through underhanded means unknown to Hua Guangsu, Wei further presses and frightens Changqing and thus brings about Qinyan's transfer into Hua's household.

Opium in this scene is something one offers to a respected guest, for whom one may load and light the pipe whether or not the other is a novice. Wei Pincai may or may not be a true novice. In this and other novels, the lack of familiarity with opium smoking includes the inability to achieve a successful draw on the pipe and may result in a potentially laughable display of clumsiness. This is of course a situation in which Wei cannot make a fool of himself. Whether the draw he takes is genuine or pro forma, he cannot possibly be on the same level with or lower than Changqing and thus will not smoke seriously or attempt to "return the favor." As for Changqing, he is already lower in social rank than Wei Pincai, who might, he hopes, be drawn closer to him by this offering of opium. As Changqing 
becomes agitated, he smokes more intensely, as if to draw energy and wits from the opium in order to fend off these representatives of the very powerful Hua Guangsu.

As imperious as Hua may be, however, he is not unscrupulous like Wei Pincai, who has two interests: one, to avenge himself upon Qinyan, who has previously insulted him, and two, to gain the better favors of Hua Guangsu. Once Qinyan is housed in Hua Guangsu's compound, which he is not permitted freely to leave, he is ultimately safer there than at Changqing's. In terms of opium, Qinyan is in potential danger wherever there are opium smokers and with anyone who smokes opium. At Changqing's, he had been vulnerable to the opium profligate $\mathrm{Xi}$ Shiyi and others who coveted his company and barged their way in. Outside Hua's palatial grounds, Wei Pincai, Xi Shiyi, and other opium smokers menace Qinyan with their machinations and lustful intentions. Hua, on the other hand, never forces himself physically on Qinyan and finally regrets having imprisoned him.

Later in the novel, Wei Pincai associates with Xi Shiyi and others who combine opium smoking with sexual liaisons with female and male prostitutes, especially boy female-impersonators. In the scenes of that world, wherever there is opium there is conniving, vulgarity, and lechery. In Zhang Changjia's terms, these would be the intemperate users of opium, the young wastrels he describes, for whom opium was most attractive as an aphrodisiac. The use of opium that Zhang considered the most immature and most easily left behind was, according to his novelist contemporaries, the most prevalent use aside from utter self-ruination. Opium according to them was only conducive to the mutually exploitative relationships between mainly two types of people: the male or female prostitute and those who owned them or bought their services. The exploitative use of opium in fact crystallized into the main way opium was seen to arrive in the modern colonial and postcolonial world. Drugs in general have been overwhelmingly defined in the context of misuse, excess, and exploitation and in that sense are the most clearly distinguished from the traditional intoxicant alcohol.

\section{Extortion and Conniving}

Both periodic enforcement of prohibitions against smoking and the general condemnation of opium production and use created a world 
in which smokers always lived under the pressure resulting from their indulgence in an officially condemned though also widely available drug. Smokers were subject to threats and loss for which they had little or no recourse to legal protection. It was possible to extort people by threatening to turn them in for smoking opium. If smokers were rich and powerful, they were less subject to the petty extortionists who were everywhere, but they were nevertheless bound to be cheated or robbed at many junctures, both inside and outside their households. For these wealthy smokers, the deception started in the household, in which servants could take advantage of a master's opium state of mind to gain favors or steal money and property. Cases like these further demonstrate how differently smokers behaved depending on factors such as gender and social status. Servants and prostitutes also smoked opium, for example, but did not necessarily lose sight of advantages to be gained from smokers of higher status.

The moneyed male addict was a spectacle, to be both envied and seduced. Opium dens, brothels, and other public settings were populated by individuals who made their living by appealing to his desires. Services were invented, at times on the spot, to satisfy his needs and to induce new ones. The female smoker was either someone of lower status living off the male addict (e.g., the prostitute), or she belonged to a privileged household and could shelter herself and her opium demands within the confines of home. The more addicted the woman smoker was, the more of a spectacle she became as well. In other words, she also became imperious in her demands and was shameless in displaying her enjoyments to those around her.

How male smokers in particular were cheated or taken advantage of can be seen in the Tower of Elegant View (ca. 1820), in which a rich addict has a special building constructed in which to enjoy opium smoking. The builders overcharge him, and the handsome boy servants he hires, "knowing he is addicted to opium," serve him his opium in order to turn his attentions to themselves instead of his wives. ${ }^{38}$ In Precious Mirror of Boy Actresses, visitors who insist on seeing the famous boy actor, Qinyan, are turned away by the boy's ownermanager, at which point the visitors break in, take the manager's opium pipe, and threaten to turn him in to authorities (Ch. 16). The same manager, Changqing, later directs his boy servants (also dressed as xianggong 相公, "female impersonators") to divert a vulgar

\footnotetext{
${ }^{36}$ Taguan lou, hand-copied edition, Beijing University Library, Ch. 9, 5b, 6a.
} 
but rich opium addict who wants to see the famous boy actor. Here, as in other scenes when boys serve opium to men, they climb into the mens' laps, hug them, and share draws on the opium pipe (Ch. $27,337)$. In another chapter, a boy persuades a young man to part with a valuable bracelet by engaging in a lengthy seduction: the boy passes liquor from his own mouth into the man's (a custom practiced between what are portrayed as vulgar boys and men in Precious Mirror of Boy Actresses and also found in other novels in brothel scenes between men and women), then massages the man, and has him lie down to smoke opium, which he likewise serves to him by passing smoke into the man's mouth. After more hugging and rubbing, the boy succeeds in obtaining the bracelet (Ch. 51, 652-53 and 22b) ${ }^{39}$

Besides servants and opium servers who take advantage of their masters and clients, others obtain money and opium for themselves by searching out better-off addicts whom they cheat and blackmail. In Souls from the Land of Darkness, Peng Yang'ou writes of a kind of "lawyer" or "pettifogger" (songshi 訟師) ${ }^{40}$ who, himself a smoker, is in cahoots with yamen runners and owners of opium dens in which he targets rich addicts whose wealth he contrives to manage. He pretends to prevent his clients from being cheated and helps them sue others who cheated them, all along appropriating large amounts of the rich addict's money (Ch. 13, 153, 157-58). This cheat is a higher version of the kind Walter Medhurst described in the 1840 s as "vagabonds" and "rascals" who "are frequently to be met with, wandering about the country, who, under pretence of searching for smuggled opium, require travellers to open their baggage," and after learning what the travellers have, plot either to rob them or extort them "by the threat of bringing them before the mandarins."

Smokers are also subject to being robbed of their opium by people who either resell it or keep it for themselves. In Souls from the Land of

39 The page number $22 \mathrm{~b}$ here refers to the traditionally bound edition of Pinhua baojian, Gest Library, Princeton University, n.d. This is the edition used for passages that are excised in the Taibei edition. Hereafter, the page number plus "a" or "b" indicates that this edition is being cited.

${ }^{40}$ Mann and Kuhn describe them as playing a significant role in nineteenthcentury local government, although they were never afforded any "legitimate place"; see Susan Mann Jones and Philip A. Kuhn, "Dynastic Decline and the Roots of Rebellion," in Denis Twitchett and John Fairbank, eds., The Cambridge History of China (Cambridge, England: Cambridge University Press, 1978), vol. 10, Part 1, 107-62, see 112-13.

${ }_{41}$ Walter H. Medhurst, $A$ Glance at the Interior of China (London: John Snow, 1850), 22. 
Darkness, a heavily addicted young bride secretly brings to her husband's household a large store of fine opium, which one night is stolen. Since opium is her "life" and she cannot expect her husband's family to buy her more, she must have it back (Ch. 10, 142). After a lengthy investigation, during which both the robbers and minor yamen officials and runners smoke and appropriate her opium, she and her husband pay a bribe to obtain less than half of the original amount back (Ch. 8). ${ }^{42}$

Another category of exploitation is the extortion of money from brothel keepers, prostitutes, and their customers. The novel Dream of Moon and Romance contains detailed enactments of this type of opium crime, the perpetrators of which recall the lawyers and vagabonds just mentioned. ${ }^{43}$ Opium addicts like the so-called lawyers in Souls from the Land of Darkness approach a brothel-keeper and ask for a loan or demand money to pay an opium debt, are refused, and later contrive a lawsuit, to prevent the consequences of which the brothelkeeper must pay a greater amount than the one originally sought. The prostitutes must inevitably give up a greater than usual portion of their earnings to meet the extortioner's demands. The brothelkeeper, moreover, must secure his own coterie of addict-friends who have connections in local yamens or know people who know the ones suing. One of these troublemakers in Dream of Moon and Romance is a heavily addicted young student who, having spent all his money on opium, now relies on extortion to maintain his supply, exacting "four silver dollars from each brothel" (Ch. 9, 62-63).

As these examples show, smokers had in common both their opium habit and its effects, on the one hand, and on the other the dangers that might arise because of the means needed to engage in the habit and the settings in which one might engage in it. Cheating and deception were common in these settings. Deception included hiding one's addiction from respectable others, while cheating ranged from outright extortion in order to sustain one's addiction, to various subtle means used to seduce or fleece someone else. In such a world, opium was a convenient tool for obtaining one's ends. This is especially the case among prostitutes, whether male or female, who were under pressure from their managers to fleece their customers as much as possible. Finally, those who did not smoke

\footnotetext{
${ }^{42}$ See Precious Mirror, Chs. 34 and 35, for another case of the theft of opium, the victim being Wei Pincai.

${ }^{43}$ See Hanan, "Fengyue Meng and the Courtesan Novel," 362-6.
} 
opium were also vulnerable to the plots of their opium-smoking relatives or friends. Male addicts in need of both money and opium were known to sell their own wives and children, as reported in numerous accounts including Ida Pruitt's biography of Ning Lao T'ai-t'ai in $A$ Daughter of Han ${ }^{44} \mathrm{~A}$ similar case appears in the following discussion of female addicts, among whom prostitutes were numerous. Their placement in brothels was commonly related in some way to the conniving of the opium addict.

\section{Female Smokers}

\section{Prostitutes and concubines}

Advice one man sought from another in opium dens or other places of gathering and smoking in some cases involved the machinations illustrated above that surrounded the life of men and women in brothels. A certain addict in Dream of Moon and Romance, for instance, might have sought connections for entering an agreement by which he would pawn his wife to a brothel but would still retain his ownership over her. Later, after his wife managed to find a rich man to buy her as concubine, the addict might have gone to opium dens seeking information about where he and his mother could purchase another girl to train in the art of entertaining men. Situations like these occur in Dream of Moon and Romance, Precious Mirror of Boy Actresses, and other novels, which leads us to the topic of addiction in women and of the scene of men and women who smoke together.

Opium dens were generally for men; there they chatted, sought advice, got cheated, or plotted how to cheat others. Where were the women smokers? They were found among the madams and prostitutes in brothels, in special opium dens where men were solicited for sexual transactions that then took place elsewhere, or they were found at home as daughters, wives, or mothers. ${ }^{45}$ Most sources about

44 Ida Pruitt, A Daughter of Han: the Autobiography of a Chinese Working Woman (Stanford: Stanford University Press, 1967).

${ }^{45}$ Moule writes: "Shanghai is unfortunately notorious for opium-smoking. In one of the streets of the French settlement, the largest opium shop in all China is to be found. It may rather be called an opium hotel, to which all classes of the Chinese community resort to learn with fatal facility the delusion of this fascinating vice, and to return after two or three visits fast bound in its well-nigh inextricable toil. Women are to be found here as well as men; and this is but the head-quarters 
female smokers are limited by the fact that they are written by men. A rare exception is a poem by an eighteenth-century woman, who refers to her opium smoking as something which induces leisurely "indolence." ${ }^{46}$ Material from interviews with women also exists, such as Maria Jaschok's study of concubines and bondservants in Guangdong Province. ${ }^{47}$ Apart from this, we must make do with secondhand information, such as a Qing male writer's citation of an "old prostitute's" comments on the effects of opium smoking on sex $(1840 \mathrm{~s}) .^{48}$ With what information we have, in other words, we must extrapolate about what women smokers specifically experienced and from that then sketch their positions as subjects within the socialsymbolic order.

In regard to opium and prostitutes, opium had indeed been a fixture of brothel situations since at least the late eighteenth century. ${ }^{49}$ The mid-nineteenth century Dream of Moon and Romance features women smokers who because of various misfortunes have fallen into contractual bondage with brothel-keepers, some of whom rent these women from their families. One such character is Fenglin 風林, an addict who is forced to engage in prostitution in order to sustain herself, her addict husband and his mother, and the brothelkeeper who houses her. The highest goal available to her is like that of other female characters in Dream of Moon and Romance and other

of a system which poisons and disgraces the streets and by-paths of the settlements and city alike" (New China and Old, 93). For the type of den mentioned by Moule, see also Flowers of the Sea.

${ }^{46}$ See the poem by Cai Wan 蒸㙀 in Maureen Robertson, "Changing the Subject: Gender and Self-inscription in Authors' Prefaces and 'Shi' Poetry," in Ellen Widmer and Kang-i Sun Chang, eds., Writing Women in Late Imperial China (Stanford: Stanford University Press, 1997), 207-8. This poem also lends support to my hypothesis above about how opium might have become (but was not) assimilated into Chinese culture by being associated with poetry that celebrated the states of mind induced by alcohol (in the tradition of Tao Qian, for example).

47 See Ida Pruitt, just mentioned; and Maria Jaschok, Concubines and Bondservants, a Social History (London: Zed Books, 1988), 14, 45-47, for mention of an opium-smoking go-between dealing in the sale of girls and young women as concubines or prostitutes, and an opium-smoking prostitute later turned concubine.

${ }^{48}$ Long-term smoking, she said, caused men to be unable to have erections and women to experience painful intercourse. "Old" could have meant anywhere from mid-twenties on. See Liang Gongchen 梁恭辰 Beidongyuan bilu 北束㯖䇤錄 (Taibei: Xinxing shuju, 1960), 3.2.10ab.

49 For brief mentions of opium among prostitutes in that period, see Wang Shunu 王曺奴, Zhongguo changji shi 中國娟妓史 (Shanghai: Sanlian shudian, 1988),

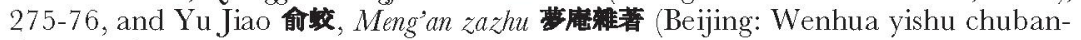
she, 1988), 372. 
novels: to find a dependable man to help her purchase her freedom and grant her legitimate status as wife or concubine, to cong liang 從良 or “redeem herself into virtue." To do so, she must navigate through her own and others' various types of dependencies: upon opium, upon her income as sexual partner, and upon attachments of emotion and obligation. ${ }^{50}$

Her story is briefly as follows: her widower father, a drinker and gambler, sells her at age seven as a child-bride to a family whose female head, Fenglin's mother-in-law, trains her to sing and play music, and at thirteen to begin engaging in "carnal transactions" (zuo hun shengyi 做葷生意, Ch. 7, 51). But her husband and his brother, heavy addicts and gamblers themselves, ruin the family business and Fenglin is pawned into a brothel in Yangzhou. There she meets an educated married man named Jia Ming 賈銘, who rents her exclusively for himself. During a period of prohibition against opium and prostitution, her brothel closes down and Jia Ming finds her a place where the two of them pass the time smoking and enjoying each other's company. When he falls ill, she nurses him. In gratitude he presents her with poems of appreciation, after which she vows devotion to him. He falls ill again, this time with an eye disease, which she cares for by licking his eyes until they heal (Ch. 28, 201). Jia Ming, however, cannot afford to buy her from her husband and mother-in-law, who meanwhile demand two hundred copper cash per day while Jia Ming houses her (Ch. 25). Nevertheless, Jia Ming treats her like a family member. When Fenglin wants to visit her parents' grave, Jia Ming at first refuses to go, but then agrees after she angrily accuses him of slighting her. He also introduces her to his wife, who is "highly pleased" with Fenglin, who is quite skillful in "flattery," "having long been accustomed to the ways of "mist and flowers," that is, the world of entertaining men (Ch. 28, 196).

One day, however, while they are in their room "passing their craving on either side of the gun" (dui qiang guo yin, Ch. 28, 201), they receive a call from a rich Hanlin scholar from the north who has heard of her and desires her company. She declines, but Jia Ming urges her to go and thus earn some money to buy another supply of opium. When she returns, she announces that she intends to accept the scholar's offer to take her as concubine. The man is a nonsmoker, already has several concubines, and gives Fenglin a large

${ }^{50}$ See also Hanan, "Fengyue Meng and the Courtesan Novel," 362-3. 
amount of silver (Ch. 29, 203). She persuades her husband and mother-in-law that since she is nearing thirty, her income-earning days are numbered and that they would do better to sell her and use the money to buy new women. As for Jia Ming, he cannot compare in status to the Hanlin scholar, but he warns her that she will find it difficult to adjust to the northern environment and may not be able to smoke her opium there (Ch. 29). She is unwavering, however, and ignores his signs of growing upset and his accusations of disloyalty. Her husband weeps as he signs the contract (maizhi 賣紙, "paper of sale") giving her away (Ch. 29, 206). She pretends not to see. Also signing the contract are her husband's brother and mother and Fenglin's own brother and sister, all of whom have been wholly or partially dependent on her income but now give way to her determination to leave. After presenting each other with mementos, she and Jia Ming spend a final night alone reclining and smoking opium. "He was full of long sighs and short, while she did not utter a word for the whole night" (Ch. 29, 207). When she leaves the next day, her mother-in-law weeps, Jia Ming curses Fenglin for not weeping, and Fenglin pretends not to hear him (207).

Angry at such lack of emotion, Jia Ming considers her to have "betrayed" him (Ch. 29, 206). From his point of view, and compared to another more self-sacrificing and nonsmoking prostitute in Dream of Moon and Romance, Fenglin is disloyal and calculating, someone about whom he and another man gather and commiserate in a teahouse soon after she leaves him (Ch. 30, 210). Fenglin, on the other hand, perhaps would not have left if yet another opium-smoking man (besides her husband and brother-in-law) had not counted upon her to entertain yet another customer in order to earn opium money. She finally cries once at the concern he shows when he reminds her that during the days of her journey she will miss her intervals of "passing her craving"; he then prepares opium for her to take along (Ch. 29, 207).

If we briefly correlate the fictional scene here with the life of a real prostitute, two points seem evident. First, a woman in a situation like this can only with great difficulty escape the accusation that she has been calculating and heartless (hence, perhaps, her silence, which hides her awareness of such an accusation). In other words, the prostitute is defined as deceptive, and in fact she is so because of her need to maneuver within her profession, from which she will do what she can to escape. Second, a prostitute about to entrust herself to marriage is at great risk, having no guarantee that this next man 
will provide more security than the last (prostitutes were known to return to their profession when marriage did not work out). ${ }^{51}$

In terms of this story, Fenglin's switch is from one man in whom she hoped to entrust herself, that is, Jia Ming, to another man, the Hanlin academician, who is of higher status and who actually buys her out of prostitution. With Jia Ming, she has already invested time and emotion. She has been intense in demanding his loyalty and respect and in showing him her devotion and need for him. Besides having chastised him for not wanting to visit her parents' grave, for example, or besides licking his eyes during his illness, she also demonstrates attachment at another time when she jealously guards him from the intentions of another prostitute, Ailin 愛林, a heavy addict who has a "face that is all the look of opium" (Ch. 27, 193). When Jia Ming invites Ailin to smoke, Ailin lies on top of him, bringing her face up to his and tickling him, after which they play for a while until Fenglin pushes Ailin aside, sits astride Jia Ming, grabs his ear, and angrily makes him a long weeping speech about his disloyalty (Ch. 27, 193-94). She rams her head against his and rolls around in a lengthy outburst of emotion. Her caring for him during his two illnesses occurs after this. Their final scene, again, is of man and courtesan wordlessly reclining in bed all night smoking opium, he full of feelings of being abandoned and betrayed, she on a course of trying to liberate herself from a life since seven of contractual bondage to mother-in-law, addict husband, and prostitution.

If opium causes a heightening of ambition and self-esteem but leaves one unable to follow through, as Zhang Changjia, Cocteau, De Quincey, and others variously may say, then Jia Ming demonstrates the opium inertia, but the prostitute Fenglin does not. Throughout her story, however, her addiction is continuous. During the opium prohibition, for example, Jia Ming takes a cure for addiction, which he urges upon Fenglin, who nevertheless still smokes secretly. ${ }^{52}$ Earlier in the novel, when another prostitute says that Fenglin is lucky to have a certain fine-quality opium, called wan-

51 On women going back and forth between prostitution and marriage in Republican era Shanghai, see Christian Henriot, Belles de Shanghai: Prostitution et sexualité en China aux XIXe - XXe siècles (Paris: CNRS Éditions, 1997), and Gail Hershatter, Dangerous Pleasures: Prostitution and Modernity in Twentieth-century Shanghai (Berkeley: University of California Press, 1997). See also Leung, "Prostitution in Modern Shanghai," in this issue of Nan Nii.

52 The recipe for the cure includes ginseng and a solution of opium ash, Ch. 25, 180-81. 
shougao 萬譆素, "long-life extract," Fenglin replies: "You are joking. We're being buried alive by this thing"-although afterwards she lies back down to prepare more opium (Ch. 7, 43).

How someone like Fenglin may experience the opium habit is briefly envisioned in a song that another prostitute in Dream of Moon and Romance sings about the prostitute's craving and entrapment:

Sister smothers, shut deeply in her room; up wells her craving draining her of life, a truly living death. Always yawning and sneezing, her eyes red and watering. Her limbs listless, she feels her whole body go soft, itchy throat, nauseous feeling, as if about to give birth. She needs to buy some mud, but she has no money; she'd like to scoop up some opium, close her doors, and pay the money later.

Smoking this dross severs me at the root. That lover of mine, he is so good to me, won't he scoop up a needleful and save my life? Then we'll live out the rest of our days sealed in our room. (Ch. 7, 48)

In terms of opium use, this and other novels together suggest three types of prostitutes: those who become addicted to the point of ruination (like Ailin or the figure in this song), those who keep their habit at a manageable level (like Fenglin), and those who view opium as something to be strictly avoided (like Qiuhen). ${ }^{53}$ Prostituteaddicts like Fenglin need opium for themselves and for entertaining their customers, some of whom are smokers already, some of whom become smokers through visiting these women, and some of whom lose all they have because of their involvement with opium and women. But while men in these novels devote everything to opium to the extent that they lead their families into destitution and rent or sell off their wives and children, the women are not in a position to be so reckless. For women like Fenglin, opium smoking cannot be as central as it is for someone like Jia Ming or Zhang Changjia. However much they suffer from their addiction, Jia and Zhang at least have some basic ownership of themselves and ostensibly, therefore, have more of a choice whether or not to ruin themselves. Or else it is the case that opium deprives these men of choice but not women like Fenglin, for whom choice must be broken down into more minute layers, that is, tactics of survival. One circuitous route of escape that women rely on takes the form of prostitution, which, however undesirable, proves all the same to be at times capable of delivering them into relative comfort. As the example below will also

\footnotetext{
${ }^{53}$ In Flowers of the Sea, 1892, one prostitute refers to another who smokes but supposedly does not ruin herself. But the first prostitute says that if she herself smoked, she could not do business (Ch. 24, 201).
} 
show, they can reject a man and take chances with another, their experience in prostitution at least training them in the arts of being pleasing and persuasive. The addict-man, on the other hand, slumps into tears and anger as he watches the addict-woman march off to take care of herself.

Juhua 菊花, a woman smoker in Precious Mirror of Boy Actresses who also redeems herself out of prostitution, does so by becoming the concubine of the heavy opium smoker described above, Xi Shiyi. In contrast to Fenglin and Jia Ming, sex is a major part of the portrayal of the relationship between Juhua and Xi Shiyi, who is also avid about sex with boy prostitutes. Precious Mirror of Boy Actresses is mainly about the chaste love affair between Mei Ziyu, a sensitive and refined young upper-class man, and Qinyan, an equally sensitive and refined younger male actor of female operatic roles. ${ }^{54} \mathrm{Xi}$ Shiyi is merely the most bullyish and profligate of a set of male characters who intrude sometimes violently upon the lives of the two main male lovers, especially Qinyan. The author, Chen Sen 陳森, as I have shown, generally draws a clear line between the virtuous and refined characters and the profligate and villainous, especially in assigning sexual activity and opium smoking almost exclusively to the villainous. Although Chen Sen focuses primarily on relations between men, Fenglin in Dream of Moon and Romance and Juhua in Precious Mirror of Boy Actresses share with the boy actors and boy prostitutes in Precious Mirror of Boy Actresses the same fate of having been forced by poverty and misfortune to become contractually bonded to people who earn a living by having them perform services for male customers. Juhua's opportunism gains her the same freedom as Fenglin's, but whereas Fenglin's narrative ends when she redeems herself, Juhua's just begins when she becomes Xi Shiyi's new concubine.

Her background and path to entrapment in prostitution, briefly paraphrased in the novel, are as follows: Originally from Wuzhou in Guangxi, she is an "extremely beautiful" young woman who at first marries a man who is "a good-for-nothing." Since she is "quite adept at social intercourse," she leaves him and forms a liaison with an official for several years, after which he leaves for Beijing. Being a "passionate and loyal" lover, she follows him separately to Beijing but fails to find him, and, having run out of money, "is forced to lean against the door and sell smiles" (Ch. 18, 230-31). Meanwhile,

54. See David Wang's discussion, Fin-de-siècle Splendor, 60-76. 
$\mathrm{Xi}$ Shiyi visits a brothel in which he is unable to strike up with any of the prostitutes because they hardly understand his southern speech and none wants to be involved with someone who smokes so heavily. Knowing Juhua is from the south like Xi Shiyi, the madam of the brothel adopts her as daughter and brings her into her house, certain that Juhua can "capture and hold on to" the wealthy $\mathrm{Xi}$ Shiyi (231). Sometime later the madam invites Xi Shiyi back to the brothel. The story now expands from paraphrase into present action of the novel. Xi Shiyi is extremely pleased with Juhua, and they enter one of the rooms together, where Juhua skillfully cooks opium for him, as translated above, while he proudly smokes his "opium noodle." She "takes several draws herself, then cuddling up to $\mathrm{Xi}$ Shiyi" helps him with several more pipes (232). Then "becoming stirred and excited, they put out the lamp, close the door, and do the "dream of Mount Wu," after which they smoke more opium, eat, and drink, continuing this way for a week. When Xi Shiyi wants to take her as concubine, the madam tries to dissuade them, but since they have already become "hotly" attached (232), Xi Shiyi pays a large sum of gold and formally sets her up as his concubine at home.

Juhua emblemizes the modest form of self-determination of the woman who is as much as possible her own go-between. She abandons her failure of a husband and pursues a long-term but nonconjugal relationship with another and more successful man. When he disappears, she turns to "selling smiles" and contracts herself to a brothel. But prostitution for her is a temporary phase of opportunism, which she leaves as soon as she enters it. As with the boy lovers in Tower of Elegant View and Precious Mirror of Boy Actresses, and as with prostitutes in Dream of Moon and Romance, opium the aphrodisiac is integral to her path of self-promotion. When other women in the brothel avoid Xi Shiyi because of his accent and the strength of his imported opium, Juhua finds in him an opium master for whom she is the perfect opium server. Knowing that he likes to take lengthy draws, she quickly learns to cook the right size bead to place around the venthole, for "she had excellent skills in preparing opium, neither over- nor undercooking it" (232). She exemplifies the basic rule of the opium server: to be observant of his or her position as manipulator of or opportunist with the master smoker. Although willing to smoke stronger opium than the other women in the brothel, Juhua nevertheless only takes "a few draws" before cuddling up to Xi Shiyi and waiting for him to become sexually aroused. It is not clear how much of an opium smoker she is, but she perhaps repre- 
sents those who maintained a moderate level of addiction, where moderate implies the ability to take care of one's livelihood.

After she becomes his concubine, the most troublesome later development is the prospect of Xi Shiyi's losing the function of his venereally damaged penis (Ch. $47,11 \mathrm{~b}) .^{55}$ The novelist completely ignores the possible effect of infection upon Juhua. She merely becomes agitated when the man operating on Xi's penis tells him it will have to be reduced to four inches long. Before she can stop herself - and just as $\mathrm{Xi}$ is in the middle of holding in his opium draw and unable to respond she blurts out to the man to leave five inches instead. Later, just before $\mathrm{Xi}$ permanently ruins his penis by taking an overdose of aphrodisiac and having intercourse with a young boy, $\mathrm{Xi}$ and Juhua have a session of sex during which he jokes with her about the hugeness of her sexual appetite (Ch. 58, 5b-6b, 745). She has thus become the butt of satire in a more than usually male-oriented novel, which now assigns her the role common to other beautiful female characters in fictional polygamies, above all Pan Jinlian 潘金蓮 in Golden Lotus (though more stereotyped than Pan Jinlian): that of the jealous and insatiable woman who is forced to wait her turn with her sexually profligate husband.

Juhua's marriage nevertheless at least delivers her from prostitution into domestic comfort and allows her to maintain her opium habit. But in contrast to the rich male addict, the opium server like Fenglin or Juhua is twice dependent: once, like the master, upon opium, but also once again upon the state of being and finances of the master, who maintains his and her livelihood. Added to this, the prostitute or boy lover must concern her- or himself with looks, age, and health. Fenglin and Juhua manage to "redeem themselves into virtue" before suffering the effects of ill health and age, about which the almost-thirty Fenglin already worries (Ch. 29, 204), or before taking on the features of the opium look: emaciation, yellowing of the skin, and blackening of the teeth-like an older, heavily madeup prostitute in Souls from the Land of Darkness (Ch. 15, 166). In weighing the reality of these concerns about age and looks, one must recall that twenty was considered "old" for a prostitute, and that the effects of opium on a person's looks could take less than a year. ${ }^{56}$

\footnotetext{
${ }_{55}$ Here and below, refer to the traditionally bound edition, which is unexpurgated.

${ }^{56}$ Numerous novels depict prostitutes who look heavily addicted, like Ailin in Dream of Moon and Romance. The effect of opium on looks was, of course, also related to diet and health. Prostitutes of the lower ranks were particularly vulnerable to
} 
When the man ruins himself, he is like Xi Shiyi, who by the end of the novel is heavily in debt, can no longer have sex because of his ruined penis, and spends night after night smoking opium (Ch. 58). If we can believe Zhang Changjia, then opium is something it is possible to enjoy in peaceful though sometimes anguished solitude or in company with like-minded friends. Even then, however, as Zhang writes repeatedly, the smoker is a teased lover who lives to hate the opium imprisonment. Some male smokers in Souls from the Land of Darkness pursue a life of solo addiction, somewhat like Zhang Changjia. Most others and those in Dream of Moon and Romance or Precious Mirror of Boy Actresses pursue a life of pleasure or profligacy in the company of friends, servers, and lovers. Some end in the same state of abandoned lover that Zhang describes, except that Jia Ming and other men in Dream of Moon and Romance are abandoned by their real prostitute lovers instead of Zhang's invisible opium companion. People of all levels - the financially self-sufficient, laborers, prostitutes, and opium servants - smoke opium to keep themselves going and to dull frustration, pain, and fatigue. Prostitutes and opium servers in addition must attend to the state of being of opium smoking customers or masters. It is only in their remaining time, if possible, that they enjoy themselves somewhat like their richer opiumsmoking compatriots. ${ }^{57}$

\section{The daughter, wife, or mother}

One type of woman, however, was particularly pampered and selfcentered in her opium habit, the unmarried daughter still residing in her parents' home. This type brings us to the topic of the other kind of female addict besides the prostitute: the daughter, wife, or mother at home, the only women, in fact, that the fiction I have considered portrays as having especially heavy addictions. The concubine Juhua also crosses into this type, but nevertheless remains more subservient than these others because of her past history. ${ }^{58}$ As la-

disease, especially venereal. A passage from the 1903 novel Haishang fanhuameng has a male addict who takes out a photo to demonstrate the difference between his face a year ago and now; see the edition with the alternate title, Sun Jiazhen 孫家振, Hualiu meng 花柳夢 (Changchun: Shidai wenyi chubanshe, 1993), Ch. 22, 240-41.

${ }^{57}$ Two boy prostitutes, for example, take turns with each other's anuses in Precious Mirror of Boy Actresses, Ch. 58, $2 \mathrm{~b}$.

${ }_{58}$ Also recall the madam Niu Shi 牛氏 of the high-class courtesan Qiuhen in The Trace of Flowers and Moon, or the prostitute Ailin in Dream of Moon and Romance, both portrayed less extensively, however, and like Juhua not free of social stigma. 
belled in The Vanity of Flourishing Life and Souls from the Land of Darkness, these more privileged women are "spoiled" in their opium habit, will have only the best opium, and must have comfortable surroundings in which to continue their life of smoking. Their opium escapism is similar to the wastrel son's except that since he is more privileged and indulged to begin with, a woman's spoiled negligence of sober norms appears yet more self-centered and outrageous.

Marriage and motherhood for such a daughter encounter special problems: 1) her state of addiction makes it harder to have high expectations for the quality of the marriage match (an addict son might have the same problem if he insists on marrying a woman from a well-placed family), and 2) the daughter must be concerned about her future supply of opium, especially if she moves into a poorer family or one in which opium is not smoked or is strongly prohibited. In The Vanity of Flourishing Life, the rich Zhou family seeks for their addicted daughter a son-in-law with both "wealth and rank," but only succeeds in finding a young man whose wealth is somewhat uncertain. The daughter's father confides to the mother that they had better not be too demanding since their daughter "has such a severe addiction to the Western extract" (Ch. 25, 473). They hasten the marriage in order to avoid allowing the son-in-law's family too much time to learn and form doubts about the daughter's "excessive addiction" (474).

The daughter, however, gives up none of her high expectations. For her dowry, although a "Western-style bed" is more readily available, she demands a bed of very rare "red sandalwood." After receiving an "imported American goose-down quilt" and many other items of fabulous luxury, she arrives at the day of the wedding and readies herself to leave her parents' home by "smoking several large draws of Western extract," thereby "nourishing herself with requisite energy" (478). But after at last packing her various exquisitely appointed utensils, she suddenly discovers that no one has seen to her supply of opium. She will not leave until she has her favorite kind of "Gold Mountain Smoke," which would take many hours for someone to set out and purchase unless, as her father finally urges, her mother takes some of her own opium to give to her daughter as they await the next day for more to be delivered (479). The addiction of mother and daughter in this case says something about not only the daughter's being "spoiled," but also the mother's. For the mother to have the best opium indicates her own privilege in the 
family. It is also tempting to imagine a bond between mother and daughter that imbued the daughter with a determination to have her way.

When it comes to their second daughter's marriage, they buy an official title for the future son-in-law Huang in order to provide him with a semblance of "fame and success" (Ch. 31, 507). By the time Mrs. Huang discovers that the Zhou daughter is a heavy addict, it is too late to withdraw from the marriage. Finally arriving at the day of the wedding, the Huangs find the Zhou daughter refusing to kneel to them in the usual manner of bride to parents-in-law, the young woman "never having paid such obeisance to anyone else before" (510). After more displays of insolence, the bride abruptly leaves before the celebrations are over and retreats to her room to smoke opium, making no effort to conceal what she is doing (511).

A similar story unfolds in Souls from the Land of Darkness when a bride who hides her addiction likewise delays leaving for the home of her parents-in-law while she "slowly passes her craving" and smokes an extra amount of opium (Ch. 9, 138). Like the women in The Vanity of Flourishing Life, she is supplied with an especially processed opium to take to her new home. When her husband later discovers her habit, the wife's servants encourage him to smoke as well, calling opium "the happiness extract," huanxigao 歡喜言, using the word huanxi with its connotation of sexual pleasure (140). "If the kind groom will smoke this opium he will be sure to add pleasure on top of pleasure, and will have a most delightful time with his bride" (140). The final part of the woman's story involves what Peng Yang'ou portrays as the consequences of opium smoking upon a woman's fertility (something that witnesses before the Royal Commission on Opium also reported about). ${ }^{59}$ In a previous chapter of Souls from the Land of Darkness, one man had already warned another who had started smoking at age fourteen that excess smoking during adolescence affected the body's development such that a man could not beget children and a woman could not commence menstruation. In this later chapter, when the woman and her husband have still had no children after fifteen years of marriage, he decides to take a

${ }^{59}$ See RRCO, 1: 30, 43, 45. A prior part of her story emerges from the mouth of the old man "Knows Everything" referred to previously who goes from one opium den to another supplying information to people who offer him opium. As her brother hears from the old man, she and her husband interest the husband's mother in opium, the husband is caught smoking opium while taking his prefectural examinations, and his prohibitionist father finally dies of anger (Ch. 19). 
concubine, asserting that his wife is infertile. The wife protests that she is neither "stone maiden" (shimii 石女) nor a person of uncertain sex (cixiong ren 倠雄人, literally, "female-male person"), and that her menstruation, regular when they first married, "is merely a little irregular lately, but it still comes every two or three months" (Ch. $21,193)$. When he does take a concubine, the wife is jealous as she looks at herself with "her face of an opium demon, blackened teeth and parched lips, not fetching in the least" (Ch. 21, 195). She tries to commit suicide by swallowing raw opium. ${ }^{60}$ Finally, a doctor prescribes a cure for opium addiction that works on both her and her husband, although she is left drained and depressed, and he has diarrhea in his clothing just as he is judging cases in court a few days later (Ch. 22, 201; Ch. 23, 202). ${ }^{61}$

The prostitute-courtesan and especially her madam or pimp, if she has one, choose or reject men depending on the mens' relative wealth. The daughter, wife, or mother stay within the conjugal family in which they display their own flair in serving their personal interests: delaying her departure for the groom's house on time, refusing to show respect to her parents-in-law, insisting on the best opium and the most luxurious items for the comfort of her new life exiled from home. She makes life center around her as much as she can and continues her opium smoking unless her situation becomes impossible, at which point in the case of the story just told she takes opium for the sake of suicide. Her self-centeredness is particularly brazen in light of the customary expectation that women be subservient and accommodating, whether marrying into a new household or yielding to a husband who wants a concubine.

\section{Male and female addiction}

How do we describe the differences between male and female addiction? The self-centeredness of the addict is the most offensive thing in the eyes of sober society. As I have said, this narcissistic withdrawal is more offensive in a woman than a man because of the

${ }^{60}$ As said previously, a commonly used method in both China and Europe; see RRCO, 1: 7, 114; and Virginia Berridge and Griffith Edwards, Opium and the People; Opiate Use in Nineteenth-Century England (London/New York: Allen Lane/St. Martin's Press, 1981), 80-81.

${ }^{61}$ Reputed cures for opium addiction had been common for many decades by the time of this novel. Such malfunction of the intestinal tract was common to addicts and those who were suddenly deprived of opium or suddenly tried to quit. 
expectation that she be more self-sacrificing than he. Proof of such an expectation is especially clear in the case of the self-indulgent man like Xi Shiyi, for whom larger-than-life excess is his motto of being. A woman could never live like he does, that is, a life in which he is able to enjoy at command frequent and highly stimulating sex. Besides a great deal of money, he counts on opium and penile force to keep him charged with an energy that gets him satisfaction when he wants it. He then goes to extreme lengths to preserve his venereally damaged penis, hiring a doctor who, after administering an anesthetic, uses a knife to cut and remold the diseased organ, which Xi Shiyi nevertheless eventually damages permanently.

Even men who are less excessive than he nevertheless share with $\mathrm{Xi}$ the expectation that they deserve anothers' devoted or servile attention. An aphrodisiac for Xi Shiyi, opium has an opposite effect for other men. ${ }^{62}$ For Jia Ming in Dream of Moon and Romance, genital sexuality becomes less driving as the hermetic life of reclining and smoking opium with a devoted prostitute fixes him in a state of Zhang Changjia-like lovesickness. But, however less excessive he may be than Xi Shiyi, Jia Ming assumes that he deserves the woman's attention and that he has no need to commandeer it. He takes up a fetal-like position of opium passivity and enjoys himself being attended to. But he is in fact no longer an infant, however infantile his feeling of being betrayed by Fenglin may be. In fact, he leaves himself utterly open to her quitting him when she finally makes the self-interested decision to seek a more secure situation.

Female addicts, on the other hand, though generally adhering to the customs of female sequestration, suspend other requirements of feminine decency and submission. Instead of doping them or making them useless, opium charges them with a certainty of their basic demands, including the demands of their addiction to opium. In charging them with that certainty, opium makes them in some guises bolder than their male counterparts. This self-certainty is particularly unnatural in the eyes of Confucian moralists or any men who share the Confucianist sense of women as nurturing and pliant. The significant point here, as I have said at the beginning of this essay, is that the effects of opium on the body may lie within a relatively constant range of physiological measurements. But factors of status

${ }^{62}$ Male addicts typically experience a decrease in libido. In an example from Qing fiction, a male smoker in Precious Mirror of Boy Actresses cannot get an erection when a young man fondles his penis. "It was as if he was in the middle of an opium craving, listless with head dangling despondently" (Ch. 47, 17b). 
and gender nevertheless make it such that addicts take their "dope" differently. In the examples above, these differences result in women attaining what amounts to a clearer political vision of their social position. Although this is not a conscious or openly articulated vision, the results are similar: the staking out of a position that overturns male expectations.

The clearest example of this subversion is something that most frightens the male prohibitionist: the potential that drugs have to empty women of their interest or capacity in mothering offspring, as occurs with Peng Yang'ou's and other authors' characters. As distressing as that abandoning of motherhood may be to some, these women in some measure escape or resist an entrapment in which they have been fixed at their expense in what has always seemed an inescapable fashion. However addicted they may be, and even if they are not addicted, some women now look at addicted men as impotent creatures. (In one novel, it is the non-addict women with unbound feet who work hard and are successful; the men in opium dens are all "useless"; Love among the Flower and Willow Girls, Ch. 24: 102-3). When men become lovesick to the point of immobility, in short, women become the nomads and the loners who leave their lovers behind. Looking at the whole of human history, Zhang Changjia writes of the unprecedented effects of opium on both smokers and China itself. Another manifestation of these unprecedented effects is the headstrong young bride unilaterally withdrawing into a room by herself to smoke opium rather than bowing to her parents-in-law in accord with hallowed custom.

\section{The doubling effect of drugs}

In Crack Wars, Avital Ronell writes about what society has against drug addicts. ${ }^{63}$ Even though she directs her attention to drugs in the West, the condemnation of addicts in both China and the West share strong similarities in the last two centuries. British and other merchants, firmly backed by their governments, sold opium to Chinese in tremendous quantities. ${ }^{64}$ At the same time, these merchants and their government backers would not think of taking opium

\footnotetext{
${ }^{63}$ Avital Ronell, Crack Wars: Literature, Addiction, Mania (Lincoln: University of Nebraska Press, 1992).

${ }^{64}$ For a recent and extremely well-documented account of opium and British imperialism, see J. Y. Wong, Deadly Dreams: Opium, Imperialism, and the Arrow War (1856-1860) in China (Cambridge, England: Cambridge University Press, 1998).
} 
themselves, for that would be "putting themselves on a level with Asiatics," as one witness to the Royal Commission on Opium once said (5: 164). But Chinese authorities similarly viewed addicts as wasted and contaminated people. The greatest likeness between Chinese and Western anti-opiumist views lies in the objection to the addict's withdrawal from normative social reproduction. The addict's "libidinal autonomy" (Ronell, 53) scandalizes the sober observer, especially in the case of the woman, whose "refusal of the organic body" (114) takes most alarming form in what I spoke of above: the possibility of her failure to nurture offspring.

Ronell also writes of the parasitic and doubling effect of drugs. "Like any good parasite, drugs travel both inside and outside of the boundaries of a narcissistically defended politics. They double for the values with which they are at odds, thus haunting and reproducing the capital market, creating visionary expansions, producing a lexicon of body control and a private property of self...." (50-51). The "narcissistically defended" entities include the civilizing and modernizing enterprise of Westerners in China, the very profitable foreign opium trade (especially as exonerated by the Royal Commission on Opium in the 1890s), and the traditional privileges of the male wastrel. What Ronell means by "doubling" is the haunting effect of entities or systems that function outside of but parallel to the narcissistic center. The doubling is also parasitic, both living off the core and also thriving independently. An example of doubling is the Chinese domestic market in opium, which doubles for that of Britain and overtakes the foreign import in quantity and value. Another example is the wastrel daughter who acts suspiciously like the wastrel son, then after her marriage keeps her husband guessing for years whether she is fertile or not, meanwhile insisting on her favorite kind of opium in her luxuriously furnished room.

What if, in Ronell's words, the woman's drug use amounts to "feminine incorporations of a phallic flux" (103)? Phallic, of course, refers to a symbolic force, not a physiological one. The wastrel woman's "visionary expansions" or "doubl[ing] for the values with which [she is] at odds" involve an assumption of phallic power. She ingests an energy of defiant strength and certainty, somewhat like the addict (libidinal autonomist) in relation to normal society or like self-sufficient China in relation to the progressive and outgoing West. Even in advanced stages of opium ugliness and dependence, she presents that image of ugliness as if in subversion of the nice way a woman is supposed to look. Then she may withdraw for good to 
her opium chamber, become the vagabond prostitute who sells sex for opium money, or perhaps procure other women who do the prostitution for her.

But whether speaking of male or female, it is not simply a matter of reversal of roles. The image of the emasculated Xi Shiyi and especially Jia Ming might suggest such a reversal in contrast to the self-certain female addict. But man emasculated and woman phallicized implies neither gender equalization or righteous victory by the woman. The new so-called phallic power is no longer conventionally aimed or harnessed anyway. Neither addict, moreover, is a normatively gendered or socialized person anymore. Opium and other drugs introduce a new type of identity, one that lawmakers still try to stamp out in draconian, that is, paranoid ways. Paranoia names the alarm about the potential deformation of the normative social and sexual reproductive cycles. Men too sensuous and women too lascivious threaten a dissolution of social productivity because of both their deficiency (uselessness) and excess. As Zhang Changjia wrote in different words, drugs outdo money in desirability, which is to say in insatiability. ${ }^{65}$ Drugs will replace and push aside conventional economic pursuits. They threaten to crowd out and pervert the more guarded flow of safer economies that still permit old hierarchies and divisions to stay in place. Opium sensuality creates new forms of "wastrelism," masculine and feminine, that open up monstrous forms of enjoyment that are normally thought to have only a mythical existence in some tabooed primordial or fantastical time (ancient orgies, alien cultures). When these monsters appear, the symbolic order as it is known until then becomes threatened as hollow and vacant. The question becomes: What were we enjoying until now that we thought was so good, when this exponentially greater form of enjoyment came along?

This last question is intended to open the subject of gender beyond what I have confined it to so far: particular examples illustrating opium smoking situations among men and women. Now it is a matter of the very system that provides for the stable definition of gender to begin with. It is both the case that opium introduces a new kind of pleasure and that opium re-introduces a deep kind of pleasure that always existed but is usually well hidden. The role of conventional order is precisely to keep that pulsating, unbridled pleasure hidden and off limits. Perhaps it is the extreme irregularity of

${ }^{65}$ A Ying, Yapian zhanzheng wenxuë, 769. 
those nineteenth-century times in China that gave a thing like opium a better chance than usual to display its effects. Those effects have always been there, but finally, at this time of modernization's leveling of cultural boundaries, exerted themselves more broadly than ever on the boundaries of sexual and social identity. In the face of such shocking luxury, Western and Chinese prohibitionists eventually overcame their mutual alienation to join in outlawing opium at the beginning of the twentieth century. In so doing, they were in effect creating a new type of global uniformity while leaving each other just enough cultural identity to maintain their basic but distinct integrities.

\section{Opium as "Foreign" Pleasure}

To put the question in literary historical terms, we should say that with opium, sexuality comes to stand for a monstrous type of enjoyment that goes far beyond that of the usual wastrel. A character like Ximen Qing 西門慶 pales before Xi Shiyi and others like him in late Qing fiction. The profligacy of Xi Shiyi, not merely a latter-day imitation of Ximen Qing and other philanderous wastrels, signals an expansion of unprecedented proportions. The reason behind this expansion lies in an idea that is not even quite accurate, but nevertheless ever-present: namely, that opium came from somewhere else, not China. This elsewhere is the West, which repeatedly and increasingly shows signs of coming to overwhelm China. The uncanny effects of opium also coincide with and resemble the uncanny and ominous effects of the arrival of the West. It is as if a new realm of both law and pleasure is about to take over, that is, a new system of law and a new, seemingly expanded order of enjoyment. These orders appear invasive because they are outside and beyond what is there now. In other words, they are irregular and uncontainable, that is, as yet unable to be accommodated and incorporated into the existing cultural system. ${ }^{66}$

Opium as something that arrives from outside is key to the promotion of prohibitionism in the late Qing, most typically coming

\footnotetext{
${ }^{66}$ The idea of the co-arrival of law and enjoyment (jouissance) comes from Lacan via Slavoj Zizek, who discusses this relationship in numerous places. See, e.g., Tarrying with the Negative (Durham: Duke University Press, 1993) and "Four Discourses, Four Subjects" in Zizek, ed., Cogito and the Unconscious (Durham: Duke University Press, 1998).
} 
across in the open assumption by the Chinese of British culpability in the opium trade. Such political messages may not appear in novels like Precious Mirror of Boy Actresses, but are nevertheless inscribed in minor details, such as the fact that Xi Shiyi himself is a trader in foreign opium or, more significantly, that one of the common names given to opium in the nineteenth century (including its novels) was yangyao 洋菒, "Western drug." British culpability and the Chinese assumption of that culpability are contained within such a term. My point is not to deny that British role, nor to trivialize what China had to do to remove itself from foreign domination and from the complex entanglement with opium. But I do wish to foreground the exaggerated role of opium as culprit, as well as the overvilification of addiction as something that necessarily causes ruination.

In such negative guises, this new drug, plus all that came along with it in the way of new things and activities, opened a hole in the heretofore comfortable order of a supposedly enclosed China (the "West" was just as enclosed in retrospect, of course). Opium had such a different effect than other known substances that it conveniently but also inevitably gave pleasure a new name. It became "foreign" pleasure (again, yangyao), and it allowed more than was ever allowed before. No matter how disciplined and strong the foreigners seemed, moreover, they at the same time represented a kind of dangerous permission that was given to opium smokers and, for that matter, anyone associated with Western enterprises in general. The permission to enjoy opium was delivered by Westerners but rejected by those in China who were against opium. To smoke opium, then, was to betray China, and all the betraying and cheating that went on among opium smokers was further proof of the obscene enjoyment that menaced China from the outside.

In effect, opium became overdetermined as a symbol and cause of China's degeneration. It was then only a minor step for opium also to become an emblem of human ruination cross-culturally. Western constructs of Chinese as "heathen" and of opium smokers in particular as "sots" played a tremendous role in this generalization (so did Western fears of demonic Asiatic masses). Hence, as I said above, the eventual alliance of Chinese and Western governments in attempting to outlaw what they together labelled as "dangerous drugs."

But the point I would also like to make is that opium played a facilitating role in dissolving boundaries both within and between cultures. Opium's effects made it obvious that only such a dissolu- 
tion could occur, even though governments would attempt to control and in some cases reverse the process (for example, through certain forms of nationalistic purification). Of course, opium as something "facilitative" has usually been an impossible thought in these last two centuries. And how opium can be thought of in such a way is something I can indicate only suggestively for now. Larger issues of imperialism and modernization have to be considered as well. I can at least highlight what is common to both the facilitative and destructive aspects of opium's symbolization, namely, as I have said, the opium smoker's extreme sensuality - his or her monstrous enjoyment. It is this that embodies what is so earth-shattering about opium's grand arrival in the world of recent times.

Since the negative symbolization of opium has prevailed in the last two centuries, I will conclude with this brief recapitulation of opium's supposed devastation. Opium in the body is like an outer menace becoming inside in a diabolical way. When women and their children are potential addicts, the "inside" that "outer" men have traditionally secluded and protected is further threatened and insulted. Again, the image of the female addict clinches the situation by superseding whatever the male addict stood for. Both ruin and salvation are thus in the hands of the woman, who is ultimately more powerful despite her apparent but actually superficial weakness. A simple example can summarize this point: As long as men alone are being addicted, it is as if they are still living within a protected fantasy world, like that of watching a battle scene or a tornado from some well-protected place. But if women smoke, it is as if men are suddenly thrown into the battle or as if the tornado all at once sweeps them away. Men alone ruining themselves is still a self-chosen fantasy world, in other words. When women make that choice, they go from being merely victim-like, that is, victims of the addicted man, to being embodiments of terrible energy and destruction. That energy may be a fantasized one, but once released, it must then somehow be recontained. This recontainment is where opium symbolization plays its role. Opium is made to stand for an alien pleasure that must be bridled. In global-symbolic form, alien pleasure is that of the other culture which threatens "ours" and against which "we" must go to war or otherwise wage a campaign of exclusion and self-purification. 